This PDF is a selection from an out-of-print volume from the National Bureau of Economic Research

Volume Title: Railroad Travel and the State of Business

Volume Author/Editor: Thor Hultgren

Volume Publisher: NBER

Volume ISBN: 0-87014-328-6

Volume URL: http://www.nber.org/books/hult43-1

Publication Date: December 1943

Chapter Title: Railroad Travel and the State of Business

Chapter Author: Thor Hultgren

Chapter URL: http://www.nber.org/chapters/c9310

Chapter pages in book: (p. 1 - 38) 


\title{
Railroad Travel
}

\section{and the}

\section{State of Business}

\author{
THOR HULTGREN
}

Occasional Paper 19: December 1943

NATIONAL BUREAU OF ECONOMIC RESEARCH 1819 Broadway, New York מ. N.Y. 
CHART

Passenger-miles, $1919-19.39$

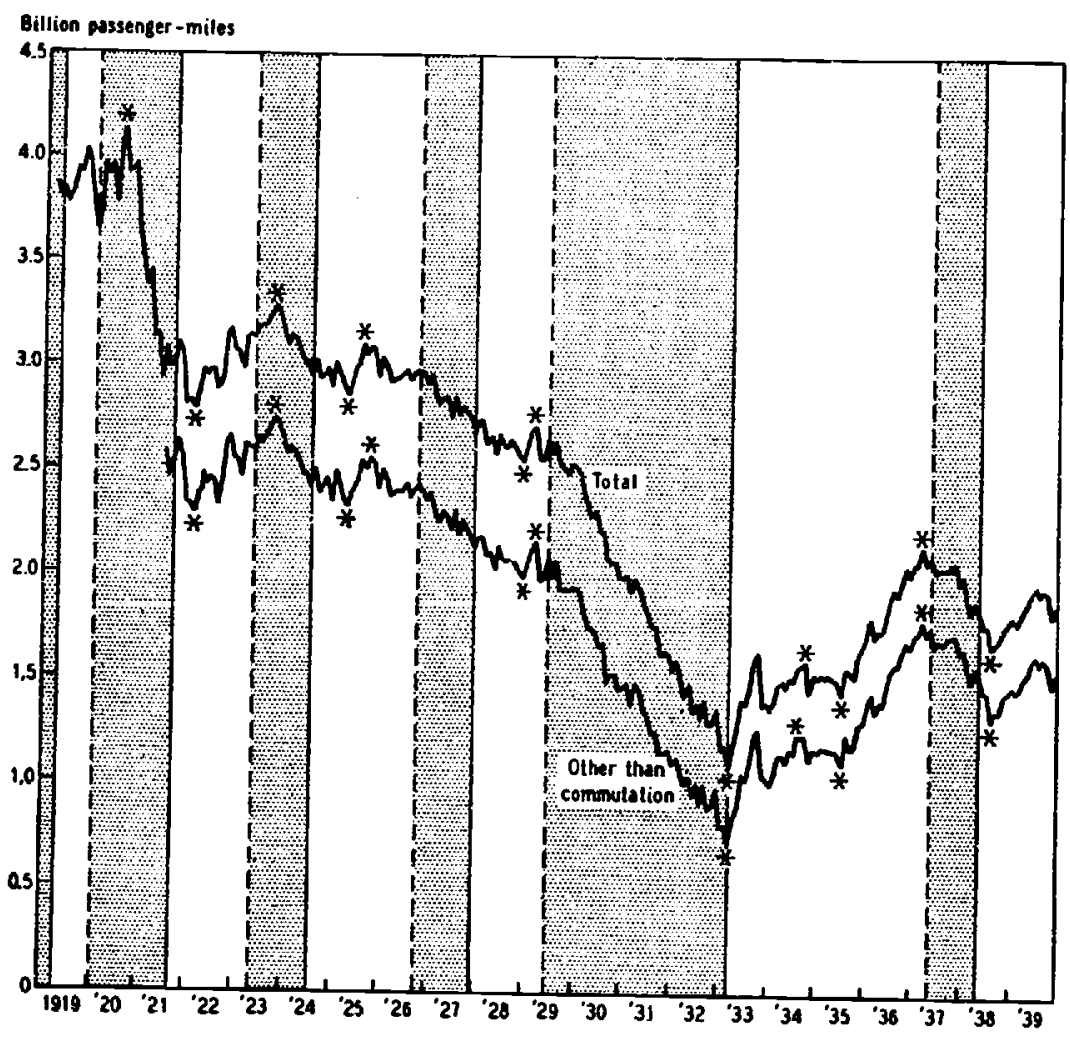




\section{CYCLES IN TRAVEL.}

Railroad travel fluctuates in rough harmony with the general disturbances in the national economy we call business cycles. The relationship becomes evident if changes in passenger miles are compared with the upswings and downswings in business outlined by the National Bureau's 'reference' chronology. A more satisfactory comparison can be made for the period since 1918 than for earlier times, as information is more detailed for recent cycles: March 1919 is the first month for which the number of passenger-miles has been compiled and published. Before then the total amount of travel was recorded in annual statistics only. We shall examine the monthly data first. ${ }^{1}$

On Chart 1 the course of railroad travel since 1919 is divided into phases of growth and decline by asterisks, one at each peak or trough. Dates the National Bureau regards as troughs in business at large are indicated by solid, and those it regards as peaks by broken vertical lines. Each interval from a solid to a broken line represents a business expansion, in which, presumably, a more or less general growth of employment, production, trade, and income occurred. The space from a broken to a vertical line represents a period of general decline, or business contraction.

Except for the 1919-20 and 1933-37 expansions, each phase of business can readily be matched with a corresponding phase of travel. For example, a few months after the business contraction of 1920 began, travel started to decline, and continued to do so during the remainder of the business phase and for some time thereafter. Differences between the turning dates in a particular form of economic activity and the 'seference' turns of the chronology are not uncommon. Indeed the dates of the business peaks and troughs are necessarily somewhat arbitrary; not all kinds of activity, even among those which clearly follow the reference cycles in a general way, reach peaks or troughs in exactly the same month.

There were no real exceptions even in 1919-20 or 1933-37. We have not marked any trough in passenger-miles corresponding to the reference trough of April 1919. But monthly data on the revenue 1 All monthly data charred or cited in this paper, except as noted, are for Class I railways and have been taken from Statistics of Railways, 1922, P. XCv, or from the monthly issues of Rerenue Traffic Statsstics. both published by the Interstate Commerce Commission. All except the earnings per mile in Chart 12 have been seasonally adjusted; that is, the original figures for normally high months have been reduced, and those for normally low months increased. The first separate figures for the two components of passenger-miles, commutation and other passenger-miles, are for July 1921. 
railroads derived from the transportation of passengers suggest that there was a trough in October 1918. As will presently appear, statistics of Pullman traffic show such a trough. We conclude that there was an expansion in total passenger-miles corresponding to the business expansion of 1919-20, although it began considerably earlier. During the long reference expansion of 1933-37, we have marked off not one but three phases in travel. It rose to a peak in October 1934, declined thereafter, and subsequently rose to a final peak in March 1937. The intermediate peak was not as high as the final one, the intermediate trough not as low as the initial one. It is fair to say that during the period as a whole there was an expansion in travel corresponding to the reference phase. ${ }^{2}$

What is true of passenger traffic as a whole is equally true of its principal component, travel other than commuting. Beginning with the 1921-23 expansion, the first for which we have data, there was a specific phase for every reference phase (Chart 1$){ }^{3}$ In arriving at this judgment we again disregard a mild specific contraction during the long expansion of 1933-37.

'Other than commutation' travel includes journeys in Pullman cars, for which we have monthly data beginning early enough to cover practically the entire 1914-18 business expansion." Here again each reference phase can be matched by a specific phase. A long expansion in Pullman passenger-miles, beginning before and ending after the reference expansion of 1919-20, is clearly defined. Again, three phases in 1933-37 can be lumped into a single longer phase corresponding to the business phase. The 1914-18 expansion presents a somewhat similar situation. Chart 2 suggests that there was a trough somewhat before the data begin in January 1915, lower than the trough we have marked in January 1916. This is exactly what we find in data on the revenue of the Pullman Company, which begin somewhat earlier. We conclude that there was a long rise from late 1914 to

2 A similar long rise, temporarily interrupted by a mild decline, occurred in many other economic activities. The declines are not sufficiently pronounced and general, however, to win recognition in the reference chronology. We consider the sharp rise and fall in 1933 too brief to be called a cycle.

3 In National Bureau terminology the periods into which the course of an activity is divided by its own peaks and troughs are called specific phases to distinguish them from the reference phascs.

4 Pullman passenger-miles, unlike non-commutation and total passenger-miles, include the travel of passengers, mosily railroad officials and employees, for whose accommodation the Pullman Company is paid, although no railroad fares are charged. The original data are from the Survey of Current Business, Jan. 1939, and subsequent issues. 


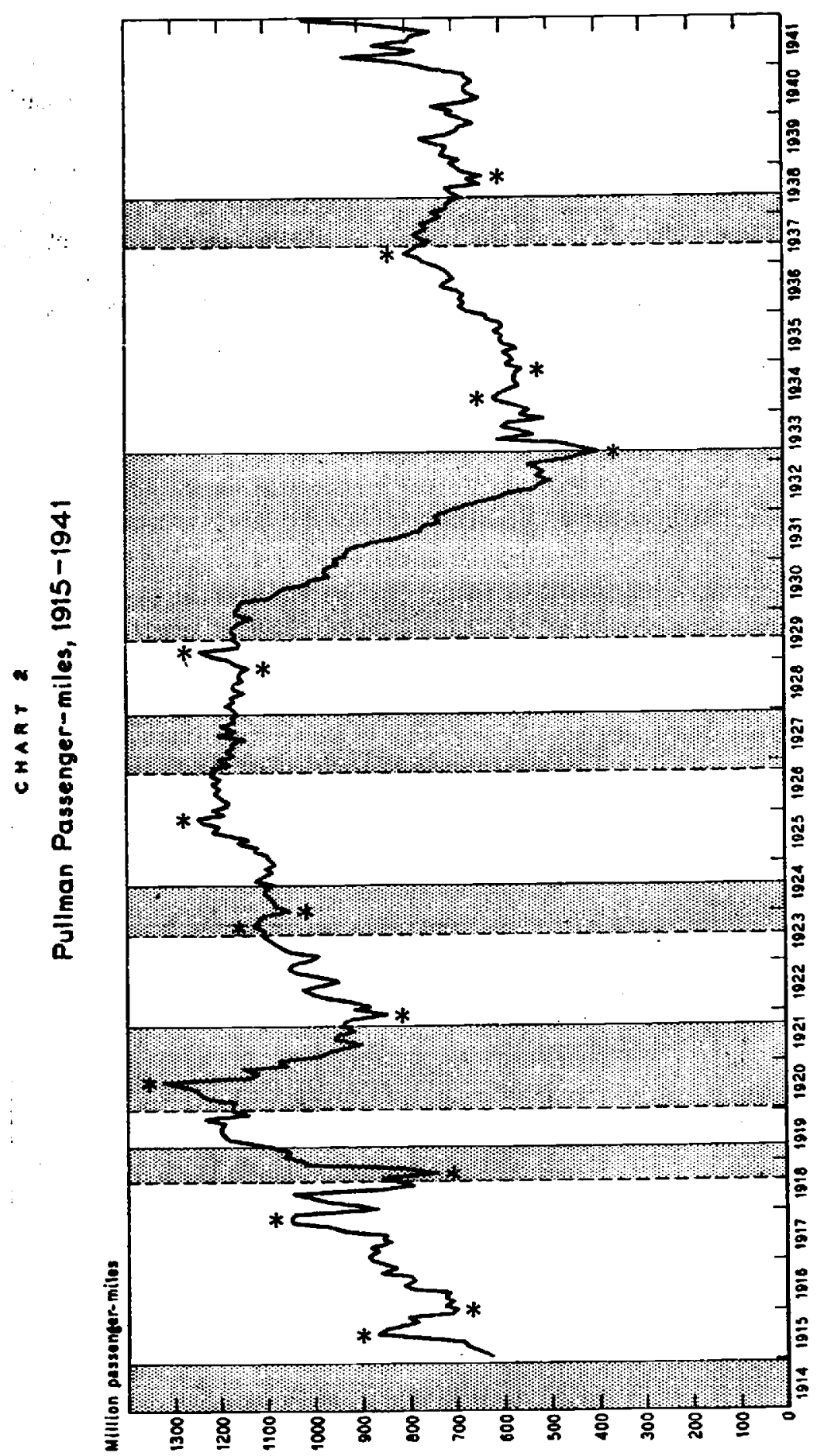


November 1917 which, although interrupted, corresponds to the 1914-18 reference phase.

It is not so obvious that there are fluctuations in commutation travel corresponding to those in business. We can see few, if any, clearly defined peaks and troughs (Chart 3); we feel unable to mark off specific cycles. Consequently we can't say that every reference phase was matched by a specific phase. But we can approach the problem in a somewhat different way by asking whether there was a net rise during each business expansion and a net decline during each contraction. We find a net rise in three of four expansions, but a decline in 1933-37; also a net decline in three of four contractions, but practically no change in 1926-27.

Since there are few cases altogether, these exceptions look formidable. Even though an economic activity rises in both an expansion and a contraction, however, it may rise more rapidly in the former. We regard such a difference in rates of growth as analogous to the difference between a rise in expansion and a fall in contraction. The resemblance is still closer if the activity rises in expansion but remains unchanged in contraction. Finally, the activity may decline in both phases, but more rapidly in contraction. Such a difference in rates of decline is also analogous to that between rise and fall. If an activity fairly consistently does one or another of these four things we say that it conforms positively to business cycles.

CHART 3

\section{Commutation Passenger-miles, 1921-1940}

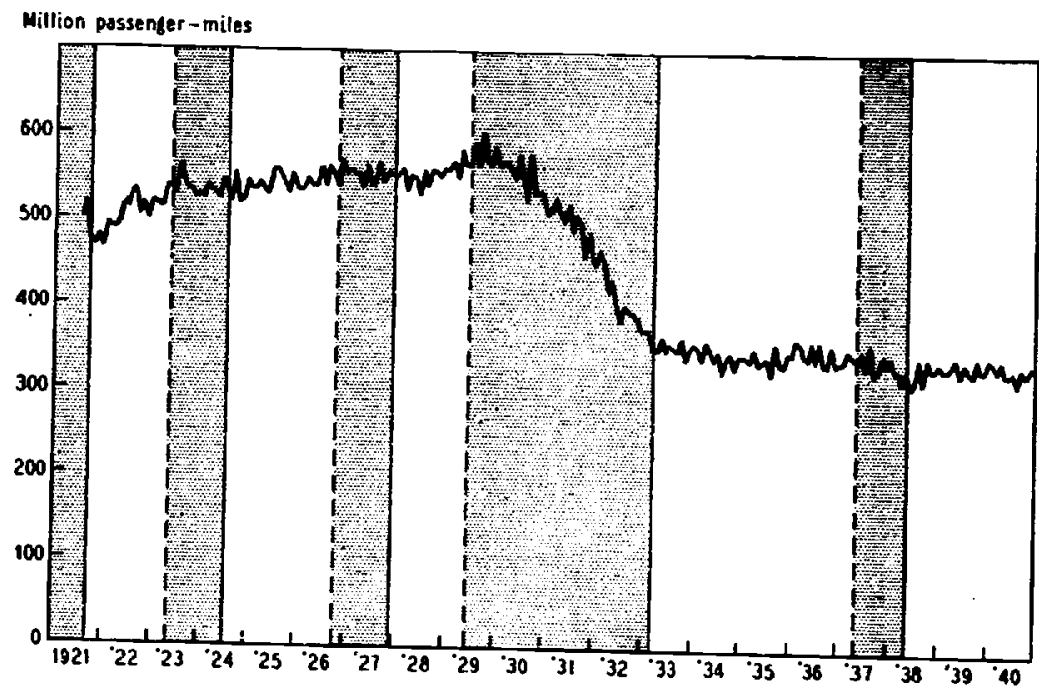


For commuting the data permit us to make seven comparisons between a reference phase and the following phase of opposite character. We can conpare the expansion of 1921-23 with the contraction of 1923-24, the latter with the expansion of 1924-26, and so forth (Table 1). Every one of the comparisons suggests positive conformity of one kind or another. If 1924-26 is compared with 1926-27, or 1926-27 with 1927-29, we find growth in expansion but none in contraction. If we compare 1933-37 with either the preceding or the following phase we find more rapid decline in contraction than in expansion. There was perfect positive conformity.

Nevertheless it is somewhat curious that commuting did not decline at all in 1926-27. In the decade after 1920, however, this kind of traffic was subject not only to changes in the prosperity of actual or potential commuters but also to another influence. During the 1920 's, although not during the ' 30 's, the population of suburban areas, and presumably the number of potential commuters, grew rapidly. The population of the New York metropolitan area, outside the large central cities, increased 52 per cent from 1920 to 1930 ; only 10 per cent from 1930 to 1940. Likewise the population of the Chicago area outside Chicago proper increased 73 per cent in the first decade but

TABLE 1

Passenger-miles

Rate of Change between Reference Months

CHANGE PER MONTH FROM PRECEDING DATE

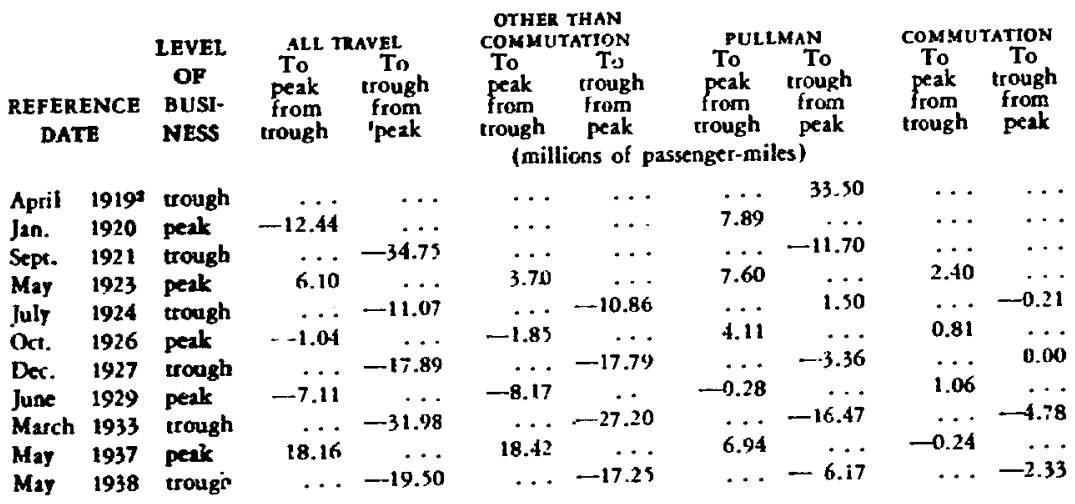

1 The method of computation may be illustrated as follows. In Juiy, August, and September 1918, Pullman passenger-miles totaled $2,471,000,000$. In the vicinity of the peak month, August, the average was therefore $2,471,000,000 \div 3$ or $824,000,000$ per month. For the trough month, $A$ pril 1919 , and the preceding and following month the average is $1,092,000,000$. The monthly average rose $268,000,000$. From August to April is 8 months. Travel increased at the rate of $268,000,000 \div 8$ or $33,500,000$ passenger-miles per month.

2 Preceding peak, August 1918. 
only 12 per cent in the second. The migration to the suburbs may have gone on, at a diminished rate, in the contraction of 1926-27; if so it would account for the stability of the traffic.

It is also remarkable that commuting should have declined, even slightly, during 1933-37, when other kinds of travel and economic activity at large were showing pronounced recovery. But after 1929 many highway improvements especially designed to facilitate the flow of motor traffic in a metropolitan region were made in and around New York and no doubt in other commuting areas. Some were completed during 1933-37. They increased the relative attractiveness of driving to work in comparison with commuting by train. Even if a traveller chose to go to and from his job by railroad, it was no longer so advantageous to buy a commutation ticket rather than pay for each trip separately. Other fares had been greatly reduced; commutation fares had not changed much. In 1933-37 ordinary fare exceeded commutation fare by about 1 cent per mile; in earlier expansions the spread was 2 cents (Chart 4). Under some circumstances the difference was nominal. The average commutation fare per mile is computed on the assumption that purchasers of monthly tickets make full use of them. Some persons had occasion to go into town only two or three times a week or preferred to drive in good weather. For them the price of a monthly ticket, divided by the number of trips actually taken, may have exceeded the new low level of noncommutation fares. Some travel was probably diverted to the 'other' category. Finally, migration to the suburbs did not add to the number of potential daily riders as rapidly as in the 1920's. All these factors help to explain the absence of any marked expansion in commuting.

We can ask the same question about non-commutation, Pullman, or total passenger-miles that we were forced by the absence of marked specific rises and falls to consider with respect to commuting. Did they conform to business cycles? In other words, we can compare the rate of net change during each reference phase with that during the following one (Table 1). Only one comparison fails to indicate positive conformity. Pullman passenger-miles not only show a net increase during the 1918-19 reference contraction but rose more rapidly than during the succeeding expansion. In the other comparisons the conformity was frequently of a modified type-not an actual rise vs. an actual fall. An increase in Pullman travel during the 1923-24 contraction was preceded and followed by more rapid increase. Non5 Computed from data in U. S. Census Bureau: Metropolitan Districts (1930), Pp. 49, 141, and releases on population and housing (1940), Series PH-1, 111, 137. 
CHART 4

Revenue per Passenger-mile

Commutation versus Other Travel

1922-1940

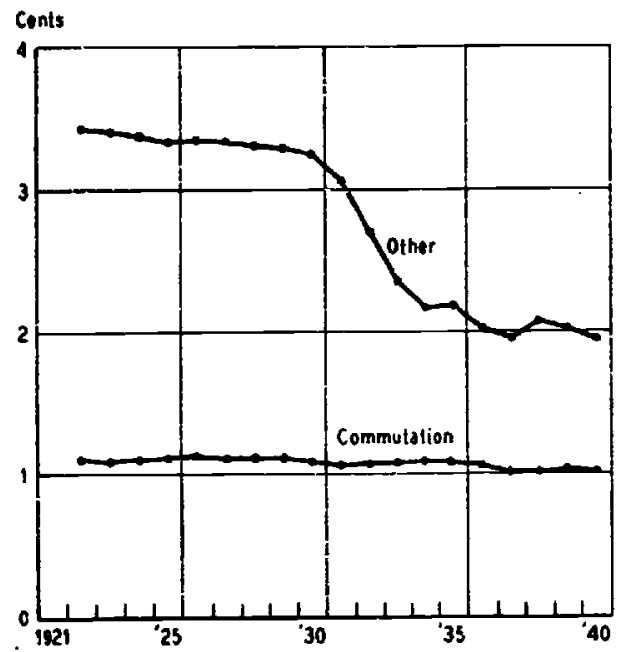

commutation and total travel declined during the 1924.26 expansion, although less rapidly than before or after. This was true of all three descriptions of travel in 1927-29.

Since there are no monthly records of total passenger traffic before 1920 , we cannot tell directly whether it conformed to business cycles as defined by the earlier monthly reference dates. But we may learn something indirectly from the figures on annual travel. ${ }^{8}$

The National Bureau has designated certain years as reference peaks and troughs. The annual chronology marks off phases that correspond in time, roughly, to those in the monthly chronology. Rise and fall per year between peaks and troughs can be computed for any phase for which there are annual data; the direction and rate of change in two adjacent phases can then be compared. Any pairing will indicate some type of conformity, positive or inverse. ${ }^{7}$ In studying activities for which we have monthly as well as annual figures, we usually find that if a comparison based on annual data indicates positive conformity, one based on monthly data also indicates positive conformity, although not necessarily of the same type. (A mere change in the rate of growth in the annual figures often corresponds to an alternation between growth and decline in the monthly figures.) It seems probable that if there were monthly figures for passenger traffic before 1919, they would indicate at least as close conformity as the annual data.

- Beginning with those for 1890 , annual data used in this paper, except those for Pullman travel, most of which were provided by the Pullman Company, are from Statistics of Railuays, 1940, p. 154. For earlier years we have relied on the data from Poor's Manual compiled in Railway Statistics before 1890 (1.C.C., Bureau of Statistics Statement 32151, mimeographed). The figures pertain to all roads (not only Class I).

7 In rare cases the rates of change are exactly the same in both phases, indicating neither type. 
We have annual records for 21 reference phases before the phase of 1919-20, the first we are able to discuss in the light of better data. Thus we can supplement our study of monthly data by 21 comparisons of a phase with the following phase, based on annual data (Table 2). The simplest kind of contrast-a rise during the expansion together with a decline during the compared contraction-appears in only 3 instances. In 10 travel increased during both phases, but more rapidly during the expansion. In one it declined in both, but more sharply during the contraction. In the remaining 7 none of these things happened.

Of the narrower descriptions of travel there is an annual statistical record for only one before the monthly figures begin. We know the number of journeys people took in Pullman cars, although not the number of miles they traveled. We may dispense with the figures for years after 1915 (except to compare 1915-18 with 1913-15) as we have monthly data for later phases. Of the 20 remaining possible comparisons 4 indicate increase during expansions and decline during contractions, 7 more rapid growth during expansions, and 2 more rapid decline during contractions; the other 7 indicate negative conformity (Table 3 ).

Thus most of the imperfect evidence from annual data suggests that in earlier times travel usually conformed positively to the changes in business at large indicated by the monthly chronology, as it did afterwards.

When traffic conformed positively to business by rising less rapidly in contraction than in expansion, we infer that although it was influenced by business conditions it was influenced also by something else which, operating independently, would have caused a rise at all times. Conversely, when positive conformity appears in the shape of a less rapid decline in expansion than in contraction, there is a presumption that something else was operating as a continuously depressing influence. Before the first World War, if we may trust the annual data, conformity commonly took the form of an increase during contraction together with more rapid increase during expansion. ${ }^{8}$ From the beginning of the railway era until 1916 railroad mileage was extended year after year without exception, whether times were good or bad. The number of places between which it was possible to travel by rail increased continuously. The quality of the service was doubtless progressively improved-trains were speeded up, connections made more convenient, equipment more comfortable. As the 8 The general course of travel in this period is shown graphically in Charts 5 and 6. 


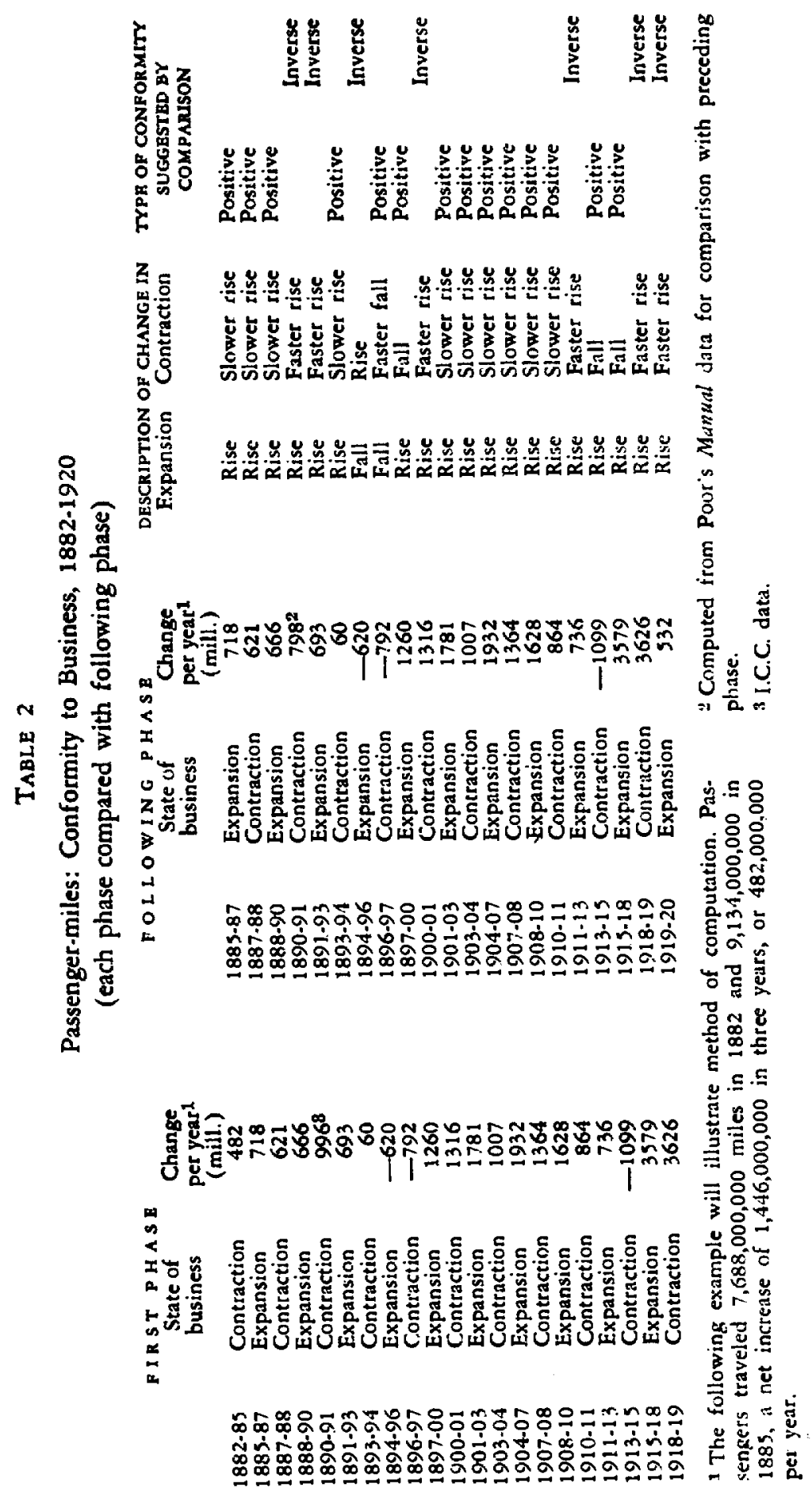




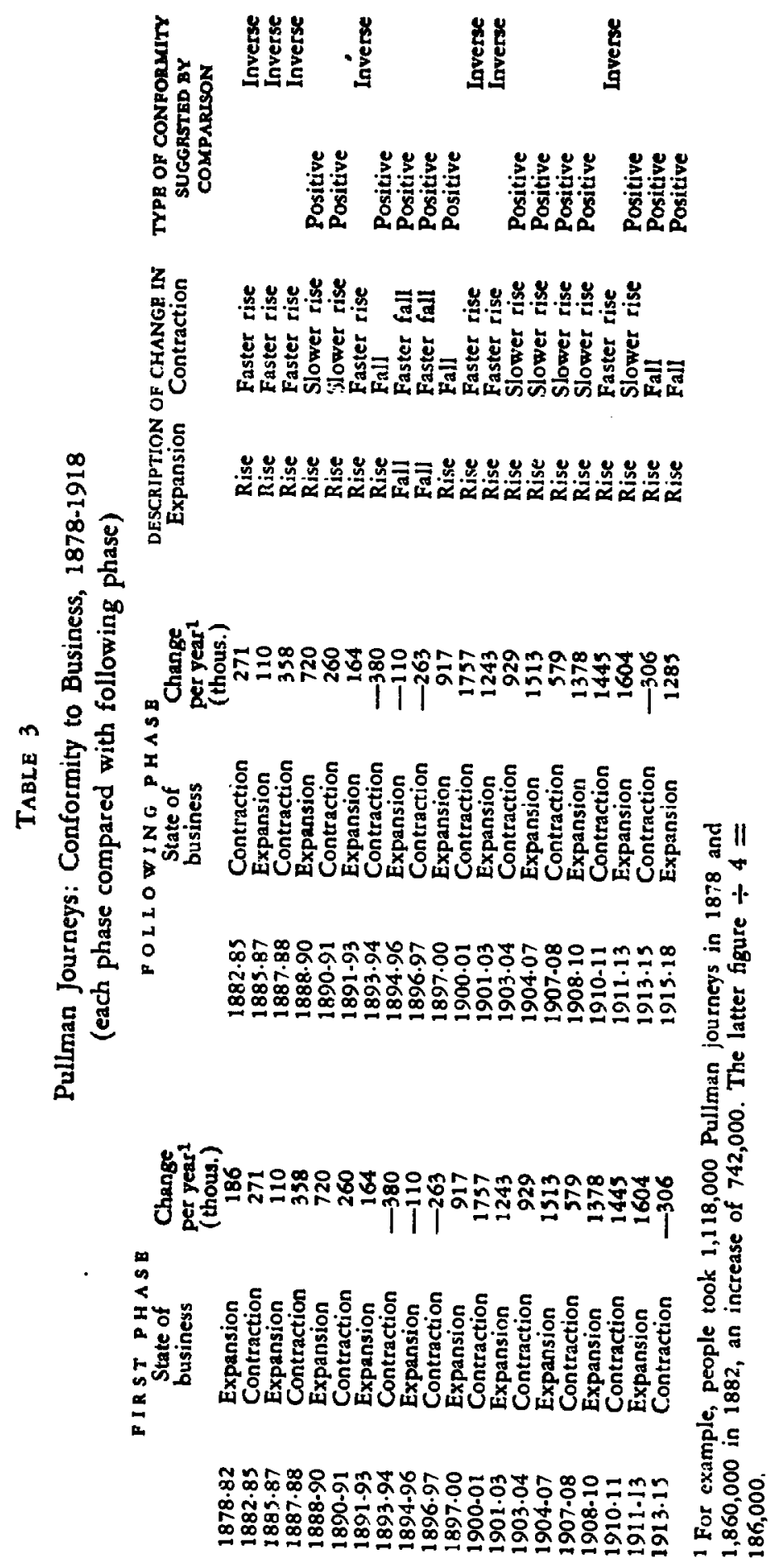


more remote parts of the country were opened, business men probably went farther and farther afield in search of customers. Even though the total sales an enterprise had in prospect might diminish. the distance traveled by its salesmen might lengthen. Improvements in service encouraged the transaction of business in person rather than by mail or wire. More and more objectives for vacation and tourist trips were made accessible. It is not unlikely that people allocated an increasing percentage of their income to pleasure travel. Even when income and business transactions were declining, travel could grow. After the war, the most common departure from rise-and-fall conformity was decline during expansion coupled with more rapid decline during contraction. During this period the improvement of roads and motor cars made highway travel an increasingly attractive alternative to rail travel.

\section{TURNING POINTS}

Peaks and troughs in travel usually occurred some time before or

$$
\text { CHART } 5
$$

Passenger-miles, 1882-1920

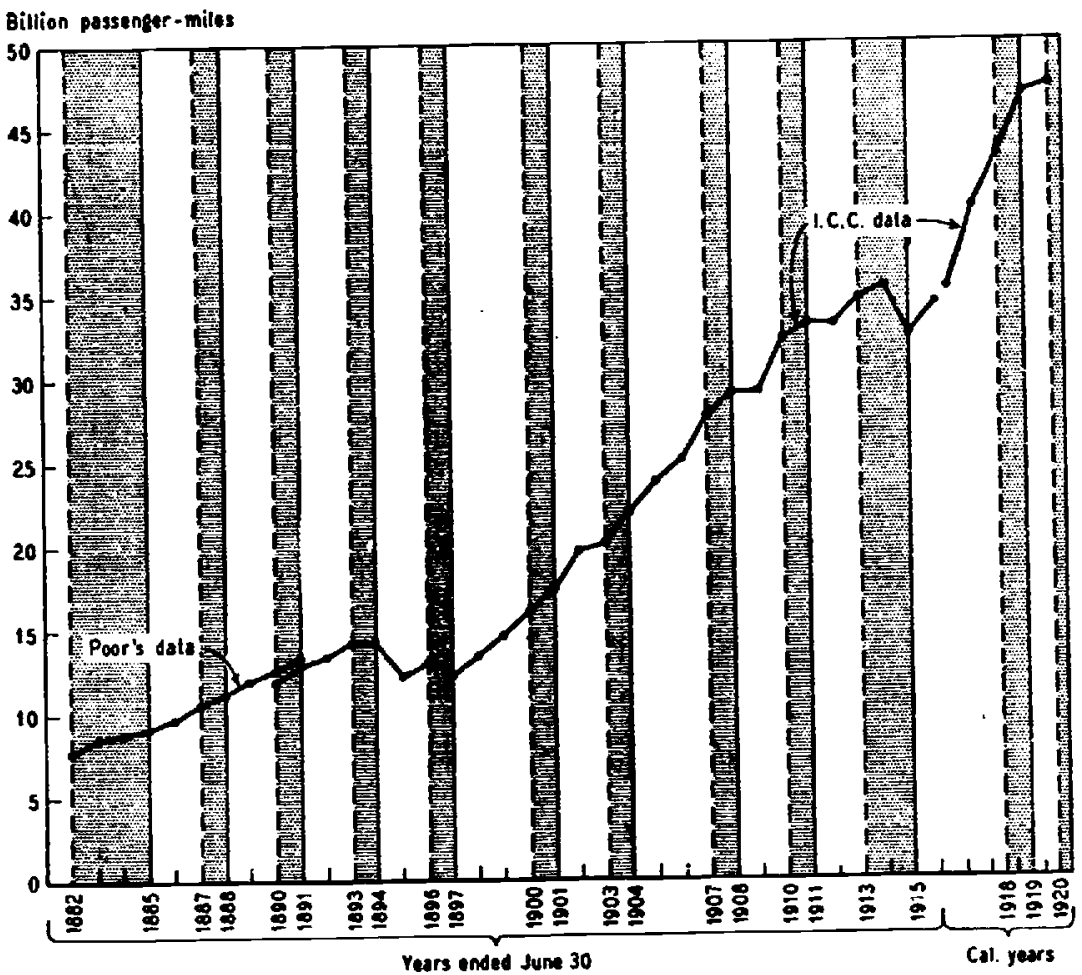


after the reference dates to which we regard them as corresponding. The twelve business turns involved may be divided into three groups: the wartime peak of 1918 and trough of 1919; the first 4 turns in the early 'twenties; and the 6 turns from 1926 to 1938 (Chart 7).

In the war period both the peak and the trough in Pullman travel preceded the corresponding turns in business. War conditions account for the dates of both specific turns.

In the earlier months of United States participation in the war, prosperity and the more numerous occasions for doing business with the government no doubt stimulated a growing number of civilian journeys. There was of course a large increase in military travel. The combination of influences produced a sharp rise in total Pullman passenger-miles from August to October 1917. The expansion of both passenger and freight traffic threatened to overburden the railroads.

CHART 6

Number of Pullman Journeys, 1875-1918

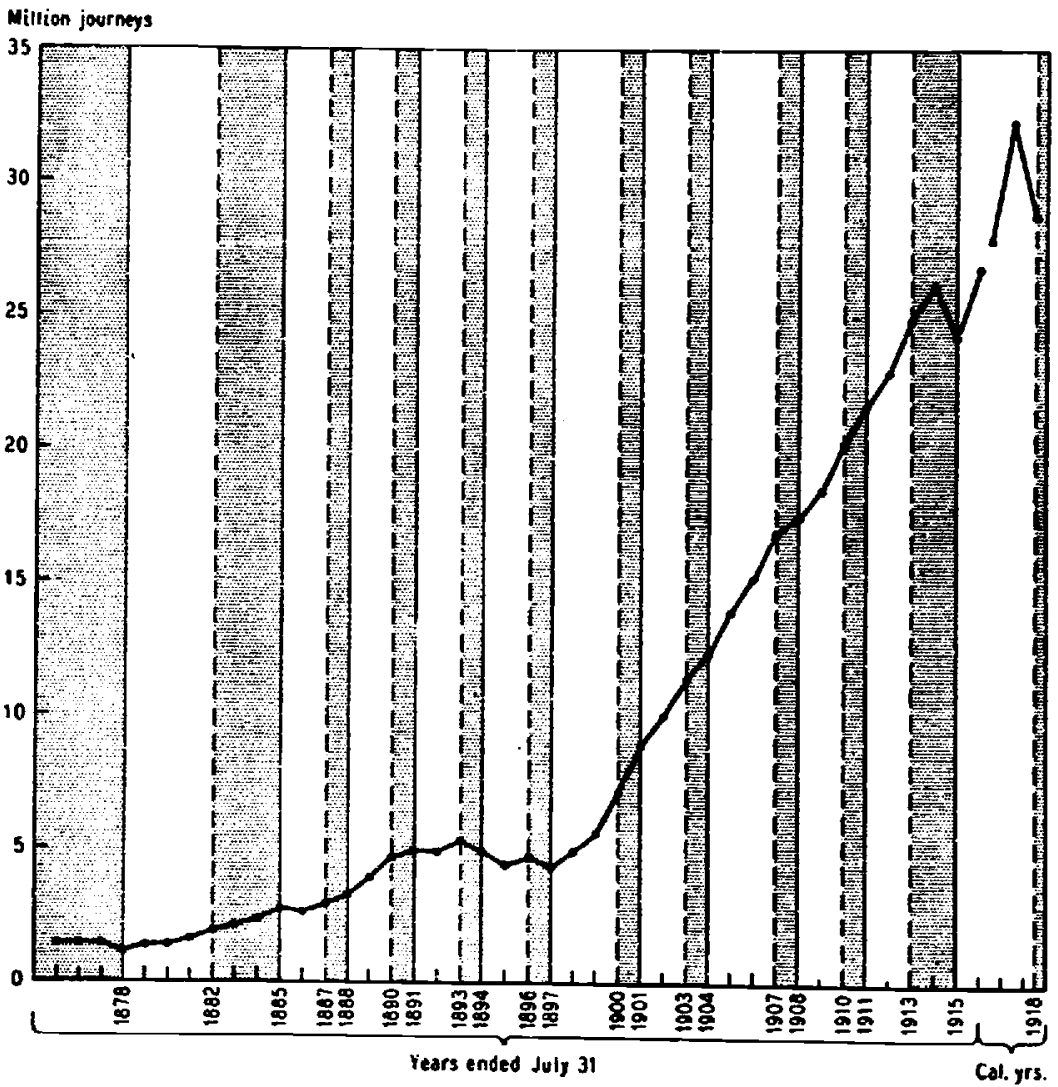


CHART T

Number of Months by which Turn in Passenger-miles

Preceded ( $(-)$ or Followed $(+)$ Turn in Business

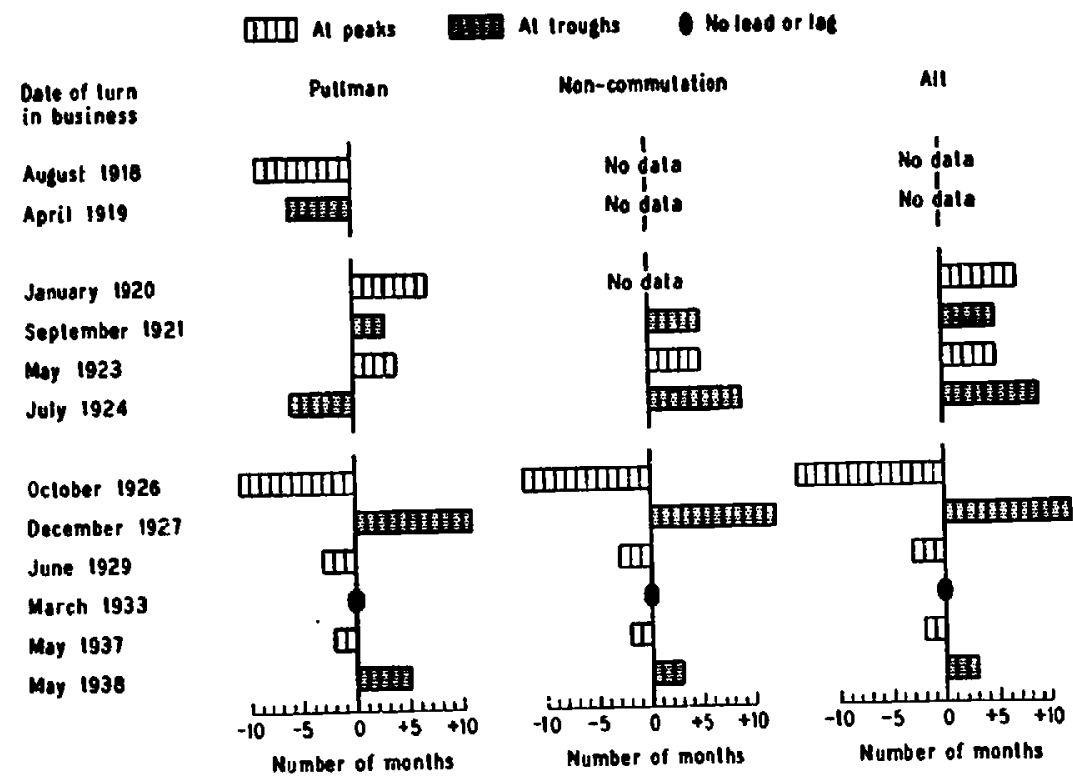

After the government took over operations at the end of 1917, it endeavored to discourage civilian patronage, partly by exhortation" and partly by running fewer trains as well as fewer parlor, dining, and sleeping cars for civilian passengers. ${ }^{10}$ Travel became inconvenient and uncomfortable as well as unpatriotic. Except for a sharp temporary rise in May, Pullman passenger-miles did not again approach the high levels of late 1917 . We attribute the earliness of the peak to the discouragement of private journeys, the decline in which was apparently too great to be offset by whatever increase there may have been in military movement.

Total Pullman travel continued to decline until it reached a trough in October, 6 months before the reference trough in April 1919. The influenza epidemic which broke out in the autumn of 1918, and which must have kept many potential travelers at home, was worst in October. Thereafter it became progressively milder. ${ }^{11}$ "Beginning with the

a See, e.g., the statement issued by the Railroad Administration and cited in W. J. Cunningham: American Railroads: Government Control and Reconstruction Policies (A. W. Shaw Co., 1922), p. 89.

10 Walter D. Hines, War History of tbe American Railroads (Yale University Press, 1928), p. 89; Cunningham, p. 90. 


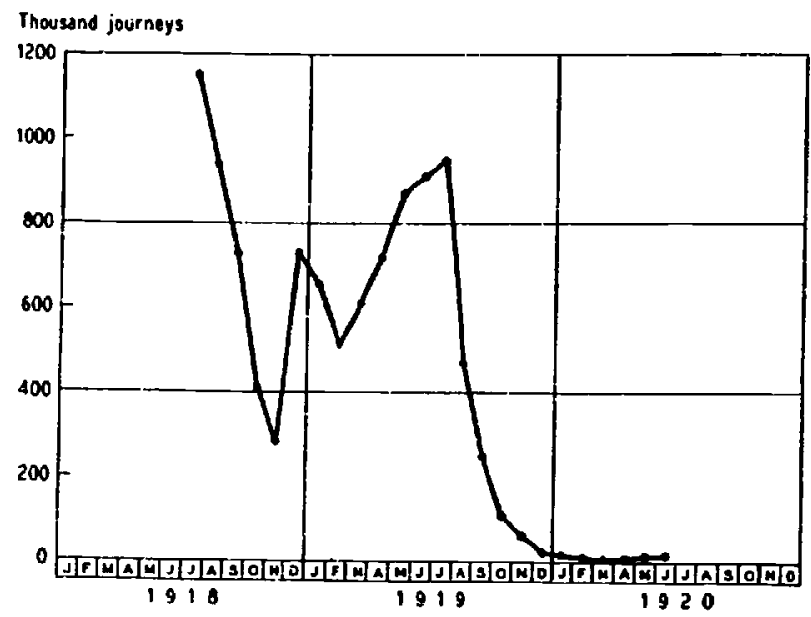

signing of the Armistice and continuing throughout the year 1919 much of the passenger service ... [previously] curtailed was reestablished." 12 People who had refrained from traveling could now indulge their pent-up desires in less discomfort and without any fear of obstructing the war. From July to November the number of soldier passengers declined; after the Armistice the soldiers began to come home in increasing number, although the movement again declined somewhat in January and February (Chart 8). ${ }^{18}$ Conditions other than the state of business thus favored an increase of both civilian and military travel for several months before April.

Between 1920 and 1924 the turn in travel came after the turn in business at both peaks and troughs, except in Pullman passengermiles in 1924. In other words, travel kept on increasing for a while after business began to decline. Once it had begun to decline it continued to do so for some time after business began to improve. We defer consideration of this group of turns for a moment.

11 Mortality rates from influenza per 100,000 population in 35 cities, raised to an annual basis, were: August, 2; September, 80; October, 1,774; November, 313; December, 445; January, 412; February, 204; March, 162; April, 66; May, 24 (Moriality from Influenza and Pneumonia in 50 Large Cities of the United States, 1910-1929, U. S. Public Health Service Reprints, Report 1415, p. 6).

12 Hines, p. 89.

13 Data from War Department: Annual Report, 1919, Vol. I, Part 4, Pp. 4919-21, and 1920, I, 1445-6. 
Between 1926 and 1938 peaks in travel regularly preceded peaks in business, and troughs in travel, except in 1933, came after troughs in business. Passenger traffic began to decline before business turned downward and continued to decline for some time after business turned upward.

The exception in 1933 came in March, the month of the banking holiday. When depositors could not withdraw money from their accounts it is understandable that all except the most necessary expenditures should be severely curtailed.

As previously noted, the growing attraction of the highways was operating to decrease rail travel during the entire period covered by our monthly data. When any form of economic activity is subject to a continuously depressing influence we often find that it turns downward earlier than business and goes on declining for some time after business turns upward. This seems to have been the case with travel between 1926 and 1938, with the explainable exception in 1933.

The first group of intervals on Chart 7 can thus be explained by wartime conditions and the third group by highway competition or the banking holiday. None of these influences is always and necessarily associated with expansion or contraction in incomes and the volume of business transactions. Only the middle group of turns from 1920 to 1924 gives any hint of what might be expected in a cycle from which these complications were absent. Even here the evidence is far from conclusive. The 1924 intervals, with total and non-commutation travel lagging behind the business trough, might just as logically be included in the third group, leaving only three cases on which to base a conclusion. ${ }^{14}$ The inference, if any, to be drawn from this fragile evidence is that, when changes in business are the only important influence at work, turning points in travel are likely to come late in the procession.

\section{THE LENGTH OF JOURNEYS}

The number of passenger-miles depends partly on how often people undertake journeys and partly on how far they go. Business conditions can affect the amount of travel by influencing either the number or the length of trips.

On the whole the average length of journeys has increased since 1921, when the data begin, both in expansion and, to a large extent, in contraction (Charts 9, 10). This was a result, at least in part, of

14 The 1924 turn in Pullman travel came early rather than late. We are unable to account for this exception on any hypothesis. 
Average Journey: Passengers other than Commuters 1921-1940

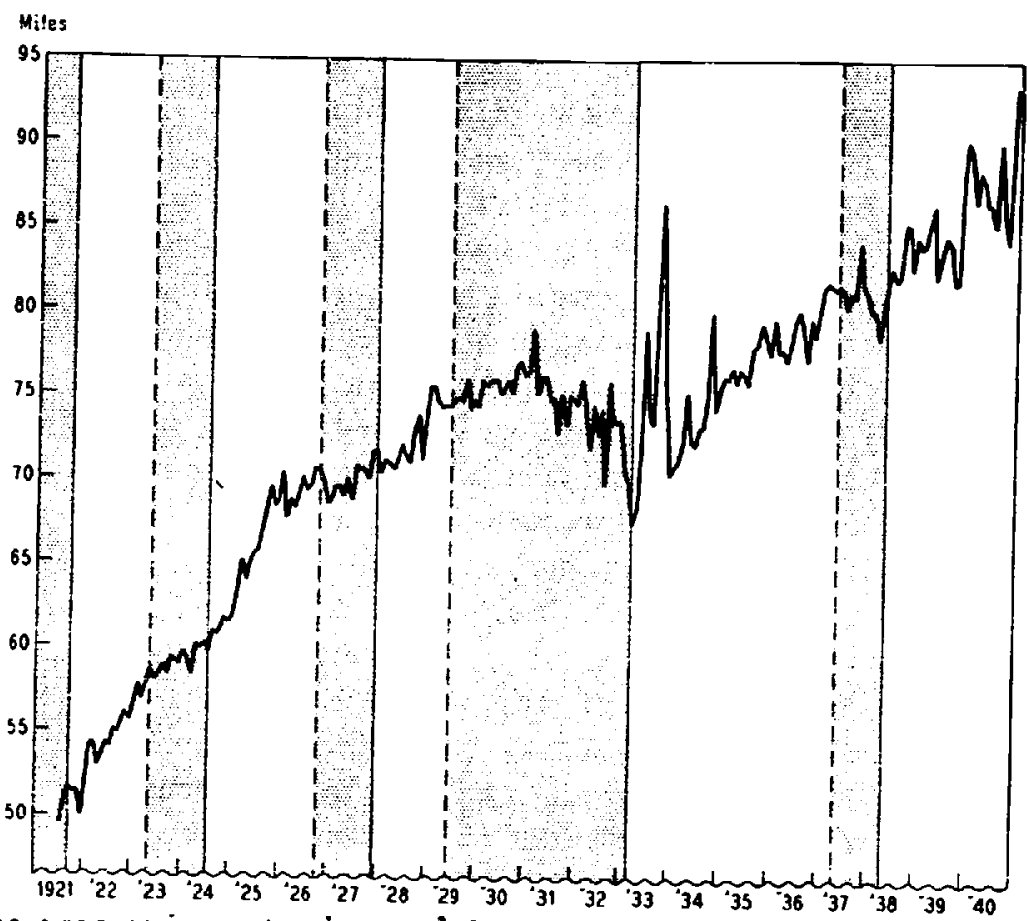

the progressive extension and improvement of highway facilities. When contemplating a short trip, people were more likely to choose automobile in preference to rail transport than when considering a long one. Driving a car may be a relief and a pleasure for a few hours; over long stretches a cumulative strain develops, the prospect of which is a deterrent. Automobile trips of great length almost necessitate an overnight stop with loss of time and lodging expense. Travel by bus for long distances was also very uncomfortable. Highway improvement eliminated short rail trips more rapidly than long ones, and thus tended to raise the average length. ${ }^{15}$

The average for other than commutation journeys, however, rose more rapidly in expansions than in neighboring contractions, and sometimes even declined in the latter, especially during the later stages of the 1929-33 contraction.

We infer that when the incomes of people who are inclined to 15 Another possible circumstance bearing especially on commuting may be cited. Later comers to the suburban areas may have established their homes farther and farther from town as earlier arrivals pre-empted the nearer sites. 
travel by rail for pleasure are increasing they take not only more numerous but more ambitious journeys. When their incomes are falling they take not only fewer but shorter ones. A similar tendency, we surmise, is present in travel for business purposes. When the size and frequency of orders is increasing it may be thought worth while to send salesmen farther and farther to obtain them. When the business obtainable per trip is declining some of the longer trips may cease to pay for themselves.

If highway transport had not been greatly improved during the period, the average would probably have increased in expansions and fallen in contractions. As things were, the average tended to rise in expansions both because highway development was eliminating the shorter rail trips and because improving business conditions were adding to the longer ones. In contraction the influence of business conditions opposed that of highway improvement.

During the first few months of the 1933-37 reference expansion a sharp rise in the average temporarily carried it to much higher levels than those which prevailed afterward. In those months the activities of the federal government were greatly expanded by the establishment of the New Deal agencies. Many people went to Washington looking for jobs; when they got them they brought their families. Business men had numerous occasions for going to the capital in connection with the new laws and their administration. Although the persons involved may have been few in comparison with other travelers they came from all parts of the country; their journeys were long.

CHAAT 10

Average Journey: Commuters, 1921-1940

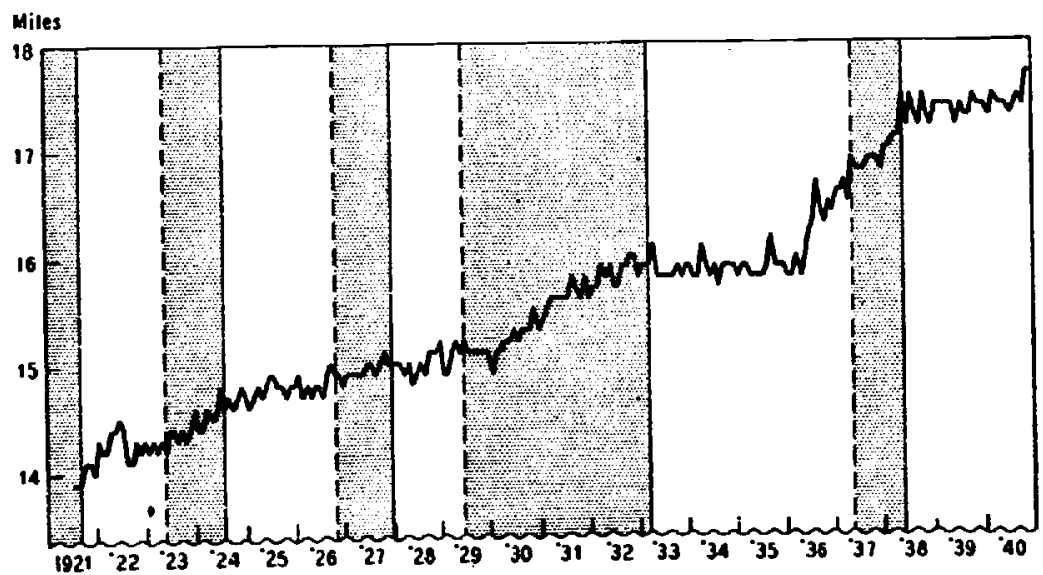


TABLE 4

Length of Journeys of Commuters and Other Passengers

Rate of Change between Reference Months

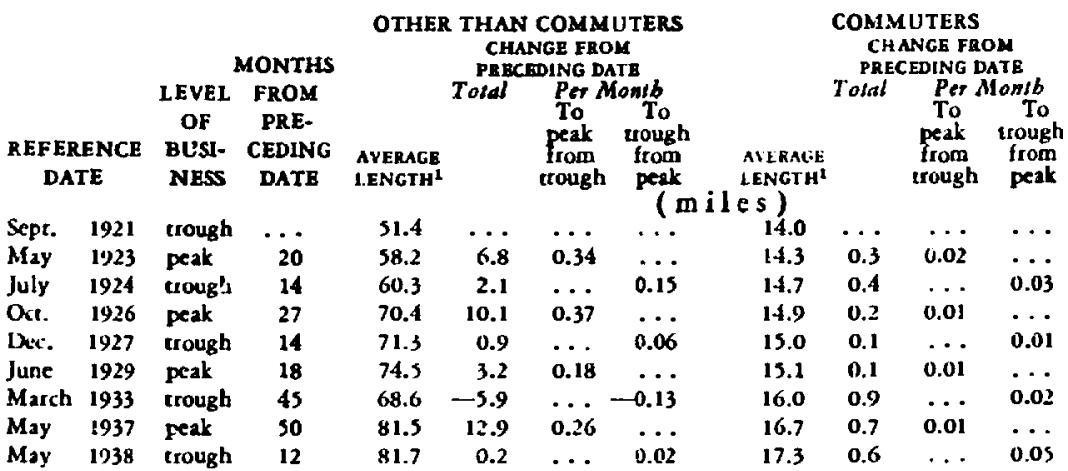

1 Pertains to three-month period: reference, preceding, and following month.

The maximum excess above the underlying slope of the curve was about 16 miles, and does not seem too great to be explained in this manner. We have disregarded these transient high levels in endeavoring to appraise the usual effect of improving business.

The effect of changes in general economic conditions on the length of commutation journeys seems to be the opposite of their effect on other travel (Chart 10). The average trip lengthens during contractions more rapidly than during expansions. Residents of the suburbs who live relatively close to the center of a metropolitan area can often reach it by bus or trolley. These alternatives are usually more inconvenient and time-consuming but cheaper. The farther out one lives the greater the inconvenience and loss of time. It seems likely that in contractions more of those who have short distances to travel drop out of the ranks of commuters than of those who live farther away. ${ }^{16}$

On Chart 10 no contrast between the contraction of 1926-27 and its neighboring expansions is clearly observable. Our usual method of computing the rate of change also fails to indicate any difference. The computed growth during the 1921-23 expansion was less rapid than during the contraction of 1923-24, however; and growth during 1927-29 was less rapid than in the following contraction (Table 4).

Since commuting accounts for a minor part of all passenger-miles, changes in the average length of all journeys are more likely to re${ }^{16}$ Arthur F. Burns suggests that persons with large incomes and stable employment may form a higher percentage of the commuters who live relatively far from town than of those who live nearby. They could more easily afford the greater fare; and in de. pression their long trips would be a greater percentage of the total. 


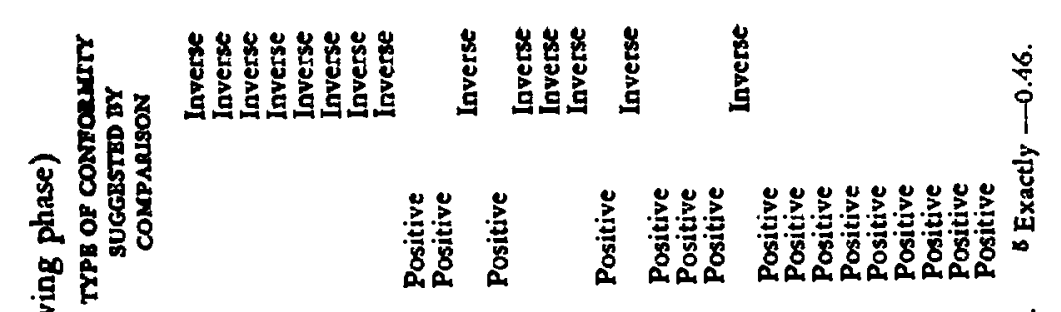

(2)

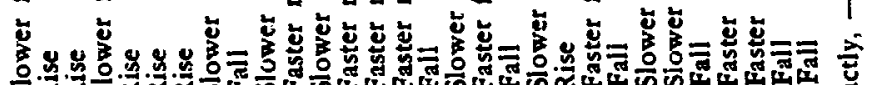

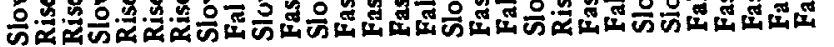

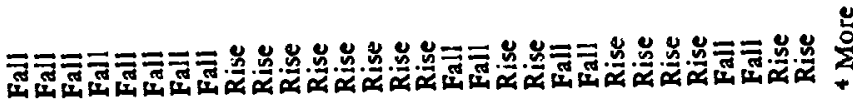

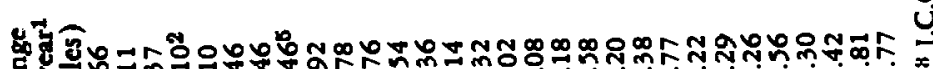
m है

í

$\infty$

$\stackrel{\infty}{-\infty}$

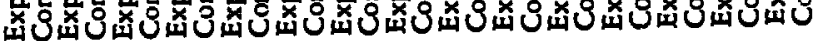

m 0

8

3

E

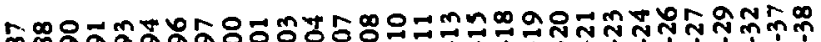

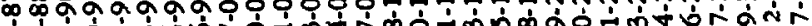
น́क

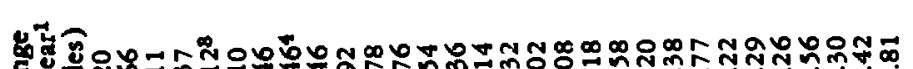

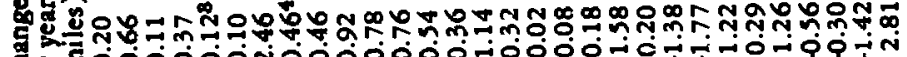

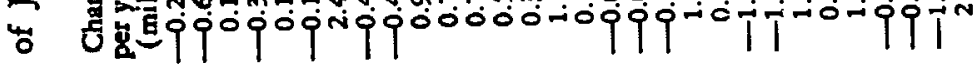
炙品

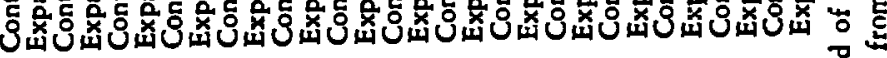

ผ็

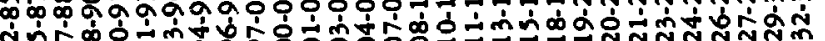

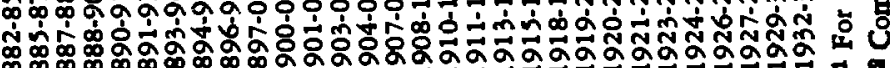


TABLE 6

I.ength of Pullman Journeys

Rate of Change between Reference Months

\begin{tabular}{|c|c|c|c|c|c|c|}
\hline \multirow[b]{2}{*}{$\begin{array}{l}\text { REFERENCE } \\
\text { DATE }\end{array}$} & \multirow[b]{2}{*}{$\begin{array}{c}\text { LEVEL } \\
\text { OF } \\
\text { BUSINESS }\end{array}$} & & \multicolumn{3}{|c|}{$\begin{array}{l}\text { CHANGE FROM PRECEDING DATE } \\
\text { Total Per Year }\end{array}$} \\
\hline & & $\begin{array}{c}\text { YEARS } \\
\text { FROM } \\
\text { PRECEDING } \\
\text { DATE }\end{array}$ & $\begin{array}{c}\text { AVER- } \\
\text { AGE } \\
\text { LENGTH } 1\end{array}$ & & $\begin{array}{c}\text { To } \\
\text { peak } \\
\text { from: } \\
\text { trough } \\
\text { (miles) }\end{array}$ & $\begin{array}{c}\text { To } \\
\text { trough } \\
\text { from } \\
\text { peak }\end{array}$ \\
\hline 1918 & peak & $\ldots$ & 371.4 & $\cdots$ & $\ldots$ & \\
\hline 1919 & trough & 1 & 367.4 & -4.0 & $\ldots$ & -4.0 \\
\hline 1920 & peak & 1 & 365.2 & -2.2 & -2.2 & \\
\hline 1921 & trough & 1 & 361.7 & --3.5 & $\ldots$ & -3.5 \\
\hline 1923 & peak & 2 & 379.0 & 17.3 & 8.6 & \\
\hline 1924 & trough & 1 & 383.8 & 4.8 & $\cdots$ & 4.8 \\
\hline 1926 & peak & 2 & 399.4 & 15.6 & 7.8 & \\
\hline 1927 & trough & 1 & 400.5 & 1.1 & $\ldots$ & 1.1 \\
\hline 1929 & peak & 2 & 420.5 & 20.0 & 10.0 & $\cdots$ \\
\hline 1932 & trough & 3 & 429.1 & 8.6 & & 2.9 \\
\hline 1937 & peak & 5 & 516.8 & 87.7 & 17.5 & \\
\hline 1938 & trough & 1 & 532.2 & 15.4 & & 15.4 \\
\hline
\end{tabular}

1 Computed by N.B.E.R.: passenger-miles $\div$ number of passengers. Passenger-miles, 1932 and prior, from Surrey of Current Business, Jan. 1939; subsequently, like all figures for number of passengers, from various issues of Statistics of Railu'ays.

semble those in other than commutation travel. Beginning with the 1919-20 expansion, comparisons of each phase with the following, using annual data, suggest in each case that the net effect of declining business is to shorten and of improving business to lengthen journeys. When there was a shortening in both phases, it proceeded more rapidly in contraction. When there was a lengthening in both, it proceeded more rapidly in expansion. Comparisons for earlier periods. however, do not, as a whole, indicate any consistent relationship. Before 1896 they suggest that improving business tended to shorten and declining business to lengthen journeys (Table 5). Annual data for Pullman travel, beginning with 1918, show positive conformity without exception (Table 6).

CYCLICAL VARIABILITY OF DIFFERENT KINDS OF TRAVEL

All kinds of travel, we have shown, tend to rise and fall with business. But are all equally affected? Is commuting more or less variable than other traffic? Within the category of non-commutation travel, are Pullman passenger-miles more or less variable than coach passenger miles?

In 1921-23 commuting increased more than other travel. In 192426 and 1927-29 it increased although other travel declined (Table 7). From these expansions one might infer that commuting was the more variable of the two kinds. But in 1933-37 commuting declined, 


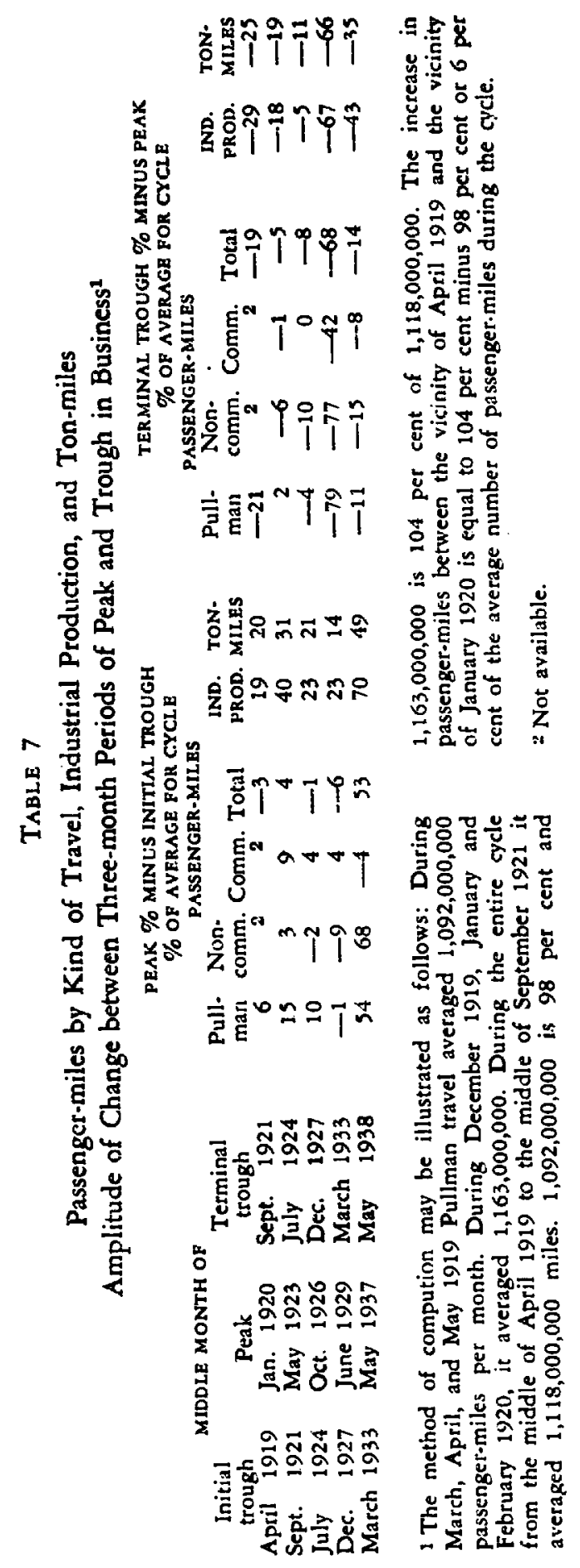


while there was a brisk rise in other travel. Turning to the contractions, we note that commuting was unchanged in 1926-27, while other travel declined; in 1923-24, 1929-32, and 1937-38 both declined but commuting declined less. Thus commuting varied less (in the direction in which business was changing) in one expansion and all four contractions. On their face these comparisons do not indicate that either is consistently more variable than the other.

Indeed they suggest that during most of the period 1921-38 influences other than business conditions tended to depress non-commutation travel relatively to commuting in both expansions and contractions. If this were true we should expect other travel to rise less than commuting in expansions and to fall more than commuting in contractions. This is precisely what happened from 1921 to 1933 . On the other hand, other travel both rose and fell more than commuting in the 1933-38 cycle. On this basis we can divide the whole period into two sub-periods in which different rules seemed to prevail. The line of division, however, might as well be placed in 1929 as in 1933 . For it would be equally true to say that other travel was more variable during 1929-38.

What these other influences may have been we should already suspect. From 1921 to 1929 the growing appeal of suburban life tended to increase commuting in both expansions and contractions; it can have had no appreciable effect on other traffic. Commuting therefore tended to rise more and decline less than other travel. After 1929 this influence cannot have been important.

It is also possible that the commutation business of the railroads was less vulnerable to highway competition than other passenger travel. The former, to be sure, involved quite short distances. But the highway alternative, if suburban residents were to go to and from business in their own cars, was a twice-daily grind of driving through congested metropolitan roads and streets at rush hours. One great disadvantage of rail travel as compared with travel in one's own car - the necessity of subordinating personal convenience to railroad timetables-was not a serious deterrent to commuting, for in this service trains were frequent and schedules were adjusted to the hours of doing business. Metropolitan highway conditions also discouraged daily travel in busses by limiting their possible speed. Rail commutation fares amounted to little over a cent per mile-less than the outof-pocket cost of driving, at least for one person per car. The increasing attractions of the highways tended to cause a greater decline in other passenger traffic than in commuting. 
Ratio of other than Commutation to Total Passenger - miles $1921-1940$

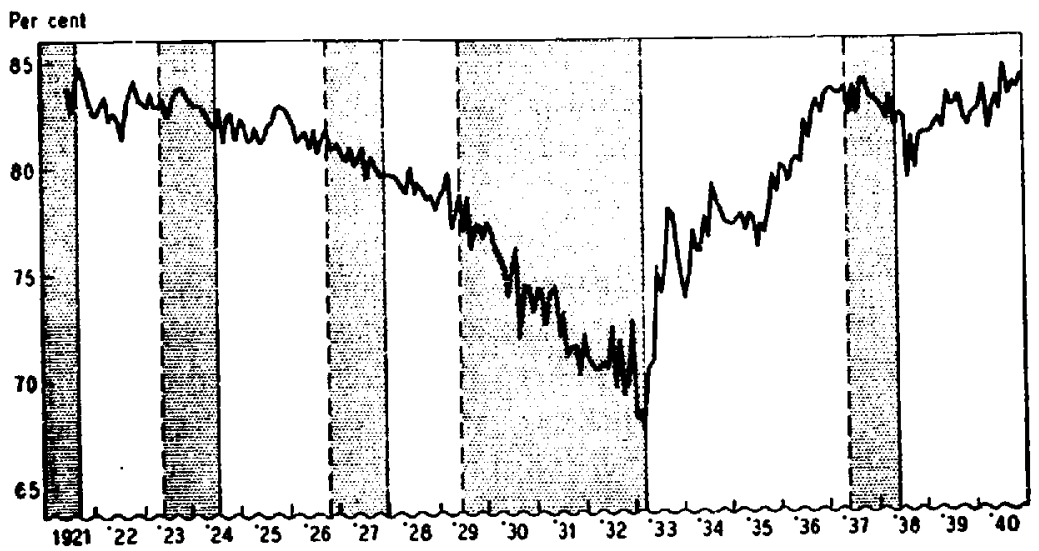

If we wish to learn anything about the comparative cyclical variability of the two kinds of traffic we shall have to disentangle the effect of other influences from that of cyclical changes in business, especially before 1929. For this purpose the ratio of other than commutation to all travel is illuminating. It declined from 1921 to 1933 , then rose in the 1933-37 expansion and fell in the 1937-38 contraction (Chart 11). The fall between 1921 and 1933, however, was uneven. The ratio declined more rapidly in each contraction than in the adjacent expansions (Table 8). This suggests that the tendency of other influences was to depress non-commutation relatively to commutation travel throughout the twelve years, but variations in business tended

\section{TABLE 8}

Ratio of Other than Commutation to Total Passenger-miles Rate of Change between Reference Months

DATE

Sept. 1921

May 1923

July 1924

Oct. 1926

Dec. 1927

June 1929

March 1933

May 1937

May 1938
CHANGE FROM PRECEDING DATE Total

$$
\begin{array}{ccc} 
& \text { MONTHS } & \text { \% NON- } \\
\text { LEVEL } & \text { FROM COMM. } \\
\text { OF PRECEDING IS }
\end{array}
$$
BUSINESS DATE OF TOTAL 1 trough $\ldots . \mathbf{8 3 . 8 8}$ $\begin{array}{lll}\text { peak } & 20 & \mathbf{8 2} .98\end{array}$ $\begin{array}{lll}\text { trough } \quad 14 & 82.20\end{array}$ $\begin{array}{lll}\text { peak } & 27 & 81.29\end{array}$ trough $\quad 14 \quad 79.58$ $\begin{array}{lll}\text { peak } & 18 & 77.84\end{array}$ trough $\quad 45 \quad 68.86$ peak $50 \quad 83.15$ trough $12 \quad 82.51$

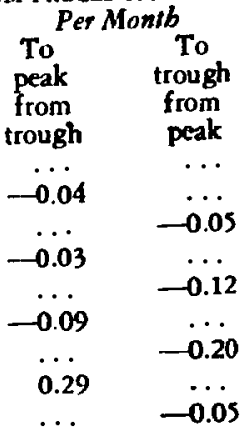

1 Percentage for reference date and preceding and following month. 
to cause greater rises during expansion and greater falls during contraction in non-commutation traffic than in commuting. If this were true, general business changes should operate against the other influences in expansion, reducing the rate of decline if not converting it into a rise, and should reinforce the other influences in contraction. accelerating the rate of decline. In other words, the ratio should conform positively to business, which it did without exception from 1921 to 1938.

There are, moreover, non-statistical reasons for believing that commuting is influenced by expansion and contraction less than other passenger business. Commuters as a class probably enjoy rather stable employment. As long as they keep their homes and their jobs they must travel to and from the city. During contractions, commuting should decline less than other travel because few jobs have been lost: during expansions, it should increase less because there are few lost jobs to be regained.

In some future business cycle the attractions of city and suburbs may have arrived at equilibrium; the proportions in which population is divided between the two may have become stable. In a similar sense, the attractions of highway and railroad as means of travel may have arrived at equilibrium. In such a cycle, we are inclined to think, commutation travel would decline less during contraction and increase less in expansion-would have a smaller cyclical amplitude-than other travel.

By comparing the changes in Pullman travel with those in total non-commutation travel, we should be able to tell whether the former is cyclically more variable than non-commutation coach traffic. ${ }^{17}$ If Pullman rises or falls more than the total, we may assume it rises and falls more than the coach component. But a simple comparison yields inconsistent results. The specific rises in Pullman passenger-miles were greater than in coach travel in 3 of 4 expansions, less in 1 (Table 9). On the other hand the specific declines in Pullman were less than those in coach travel in 3 contractions, greater in 1 . In half the cases. Pullman travel varied more, in the other half less than coach travel. Again the period 1921.38 can be divided in two parts. From 1921 to 1929 Pullman travel rose more in prosperity, fell less in depression. Other influences seemed to be depressing coach relatively to Pullman travl in both expansion and contraction. From 1929 to 1938 the relative changes conformed to no simple rule. Pullman travel declined ${ }^{17}$ Even though. as explained in foctnote 4, we cannot determine coach passenger-miles
by deducting Pullman from total. 


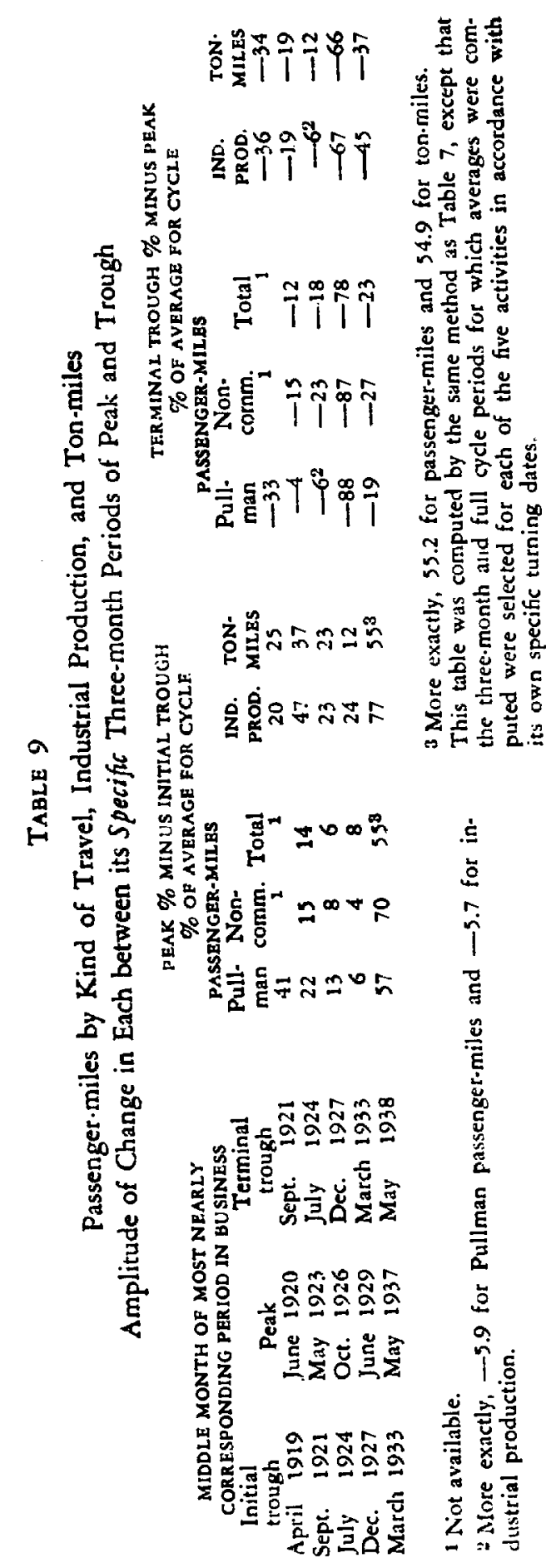


Revenue per Passenger-mile (Non-commutation)

1921-1940

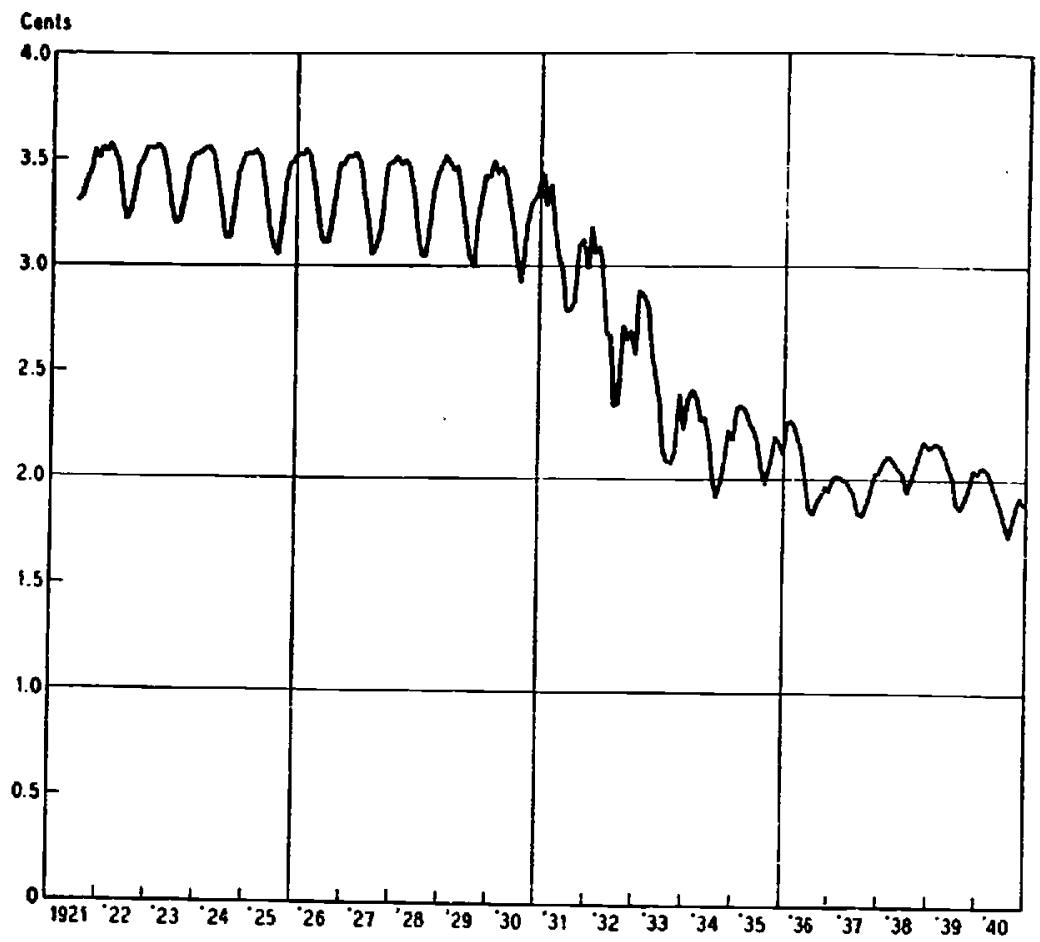

more in 1929-33, increased less in 1933-37, declined less in 1937-38.

The consistent depression of coach relatively to Pullman travel from 1921 to 1929 can probably be accounted for by a difference in their susceptibility to motor competition, traceable to a difference in the typical distance traveled. Pullman journeys are longer, on the average, than journeys in day coaches. In 1922 the average journey, other than commutation, was 55 miles. The average journey in Pullmans was 370 miles. $^{18}$ Since people are more likely to prefer highway to rail transport for a short journey than for a long one, the multiplication and improvement of roads and motor vehicles at first threatened coach more than Pullman travel. Such a difference could 18 It is true that when a passenger rides continuously over several railroads, each counts him as a passenger, and the figure of 55 miles is therefore too low to represent the average completed journey. But the latter can hardly involve, on the average, more than 2 or at most 3 railroads. Travel between New York and Chicago usually involves the use of but one railroad; many trans-continental trips involve oniy 3. As the other-thancommutation figure includes Pullman travel, the figure for coach travel only would be lower. 
cause Pullman travel to increase more in expansions, and to decline less in contractions, as it did.

The greater decline in Pullman passenger-miles from 1929 to 1933 may be the consequence of a change in the relative fares. In this contraction passenger fares were gradually but, on the average, substantially reduced (Chart 12). During most of the period reductions were not made according to any comprehensive plan; the decline in the average is apparently the result of scattered, local experiments with lower fares as a means of regaining traffic. No detailed information about individual reductions is available, but it seems possible that coach fares were more severely and extensively cut than Pullman fares. If so, the reductions may have limited the decline in coach more effectively than that in Pullman travel.

The process of cutting fares culminated in the reduction of the basic charges during the expansion of 1933-37. While both Pullman and other fares were reduced, the differential cost to the traveler of Pullman as compared with coach journeys increased (Table 10).$^{10}$ The widening of the margin may explain the greater recovery in coach than in Pullman travel. Striking improvements in the comfort and attractiveness of coach equipment were a contributing factor.

In the remaining phase, 1937-38, coach declined more than Pullman travel. The Pullman differential was narrowed in the South during the contraction, but this change in price relationships in one region seems tou small to account for the comparative change in the national figures.

The relative changes in all these phases, except perhaps the last, can plausibly be explained in terms of other factors than changes in general business conditions. They do not indicate what would happen in a phase in which the latter was the sole important influence. If either kind of traffic is consistently more sensitive to changes in business conditions than the other, the difference cannot be very great. At least it was small enough to be obliterated by differences in their susceptibility to motor competition and by changes in price differentials. ${ }^{20}$ 19 A basic fare is an amount in cents per mile ordinarily used over a wide area to construct the actual fares. Because of excursions, vacation fares, application of short-line fares over longer competing routes, etc., the average revenue per passenger-mile is usually less than the basic fare. Of the competitive reductions after 1929, none, until 1932, was widespread and uniform enough to justify describing the readjustment as 2 new basic fare, although the collective effect was substantial. Chart 12 therefore shows earlier reductions than Table 10.

: We have computed month.by-month ratios of Pullman to non-commutation travel but their evidence is no more condusive. 
TABle 10

Basic Passenger Fares, All Changes since August 25, 1920 (cents per mile)

$E \wedge 5$ T

DATE FIRST EFFECTIVE

Coach Fare

Aug. 26, 1920

July $1,1932^{1}$

Jan. 1, 1933?

April 1, $1933^{3}$

Dec. 1,1933

June 1, 1936

Nov. 15, 1937

Dec. 15,1937

July 26, 1938

Jan. 15, 1939

Mrrch 24, 1940

Pullman Fare

Aug. 26, 1920

July 1,1932 i

Jan. $1,1933^{2}$

April 1, 19333

Dec. 1,1933

June 1, 1936

Nov. 15, 1937

Dec. 15,1937

July 26, 1938

Jan. 15, 1939

March 24, 1940

Pullman Cost

Aug. 26, 1920

July 1, 19321

Jan. 1, 19332

April 1, $1933^{3}$

Dec. 1, 1933

June 1, 1936

Nov. 15, 1937

Dec. 15,1937

July 26, 1938

Aug. 1, 1938

Jan. 15, 1939

March 24, 1940

Pullman Differential:

Aug. 26, 1920

July 1, $1932^{1}$

Jan. 1, 19332

April 1, $1933^{3}$

Dec. 1, 1933

June 1,1936

Nov. 15, 1937

Dec. 15, 1937

July 26, 1938

Aug. 1, 1938

Jan. 15, 1939

March 24, 1940

2.0

2.0

3.0

3.72

1.72

1.22

1.256
S O T H

ROUND TRIP

Long Short

ONE return return

WAY limit limit

$3.6 \quad 3.6$

1.5

2.0

1.5

2.0

$2.5 \quad 2.0$

$2.5 \quad 1.5$

$3.6 \quad 3.6$

$3.6 \quad 3.6$

$2.88 \quad 2.88$

$1.5 \quad 1.5$

$2.0 \quad 2.0$

$1.5 \quad 1.5$

$2.0 \quad 2.0$

$1.5 \quad 1.5$

$2.88 \quad 2.88$

3.6

$2.00 \quad 2.00$

3.0

3.0

$\begin{array}{ll}3 & 3.0 \\ 2 & 2.0\end{array}$

2.25

3.6

3.6

3.6

ROUND TRIP

Long Short

ONE return return

WAY limit limit

$\begin{array}{lll}3.6 & 3.6 & 3.6\end{array}$

$\begin{array}{lll}2.0 & 1.8 & 1.8\end{array}$

3.0

3.0

$2.5 \quad 2.0$

$4.68 \quad 4.68$

4.08

3.72

4.68

4.68

3.96

4.68

3.96

$3.08 \quad 3.08$

$4.08 \quad 4.08$

$3.22 \quad 2.72$

4.68

4.68

4.68

2.25

2.72

2.97

2.97

$3.756 \quad 3.756$

$3.256 \quad 3.006$

3.75

3.256

3.006

1.08

1.08

1.08

1.08

1.08

$1.58 \quad 1.58$

2.08

2.22

2.08

2.08

$1.72 \quad 1.22$

1.72

1.22

0.72

0.97

1.17

1.756

1.256

1.006

1.756

1.506 
Travel is not only largely a service to consumers but, like all services, is perishable. Production and consumption are simultaneous. Travel is analogous to the production of perishable consumer goods, generally regarded as one of the forms of economic activity least affected by cyclical changes in business. Are the changes in travel that correspond to changes in business also relatively mild? To answer the question roughly we may compare changes in travel with those in the Federal Reserve index of industrial production (Tables 7,9), which reflects the production of many kinds of articles-producers' and consumers', durable and non-durable. Presumably the cyclical changes in it are greater than the changes in the production of perishable consumer goods and services. If travel changes rather little as business changes, the amplitude of its fluctuations should be les's than those of fluctuations in the Reserve index.

All four of the specific expansions in industrial production were greater than the corresponding specific expansions in travel. Two of the declines in production were greater than those in travel, but two were smaller. In 6 of 8 instances, therefore, the specific rises and falls suggest that industrial production is more variable cyclically than passenger traffic.

If the net changes between reference dates are compared, the results are similar. In 1921-23 and 1933-37 production increased more than traffic. In 1919-20, 1924-26, and 1927-29 it increased while travel showed a net decline. Thus in all 5 expansions it moved in the same direction as business to a greater extent than travel did. ${ }^{21}$ In three contractions industrial production declined more than travel;

21 Since we do not have data for the earlier months of the specific cycle in travel corresponding to the reference cycle of 1919-21, we cannot calculate the average volume of traffic for this cycle or the variation about the average. Hence we have one more reference cycle than we have specific cycles.

Nates to Table 10

Based on information in Seasonal Variation in Railway Passenger Revenue and Passenger-Miles (Interstate Commerce Commission Statement No. 4037, 1940), Pp. 10-1.

1 Changes effective only on parts of Southern Railway.

2 Changes effective only on Southern Railway.

3 Changes effective only on Louisville \& Nashville, Mobile and Ohio, Nashville, Chattanooga, and St. Lovis, and Central of Georgia railways.

1 Pullman fare plus Pullman charge for berth or seat of 0.72 cents through July 31 , 1938 , and 0.756 beginning August 1 ; plus, also, Pullman surchange of 0.35 cents through November 30, 1933 in South and West, and May 31, 1936 in East.

5 Pullman cost less coach fare. 
in two it declined less. Eight of ten comparisons suggest that production was more variable.

But much of this evidence of apparently greater cyclical variation in production than in passenger-miles can be interpreted in terms of growing highway competition, in the absence of which the increase in travel would have been greater in all the expansions than it was. The growth of employment, income, and occasions for business transactions operating alone might, for all the data tell us, have evoked a larger increase in travel than occurred in production. ${ }^{22}$

On the other hand, highway competition may account for the greater fall in passenger-miles than in production during the contractions of 1926-27 and 1929-33. In its absence travel would not have declined as much as it did, perhaps not as much as production. Thus all expansions and two contractions afford no conclusive test of the relative amplitudes that would have resulted solely from general changes in income, business transactions, etc.

There remain three contractions (1920-21, 1923-24, and 1937-38) in which the decline in production was greater than in travel. Highway competition cannot account for the difference in amplitude; without it travel would have been even more stable. These three phases suggest that business contraction, and presumably, business expansion involve milder changes in travel than in industrial production. The evidence of all other phases either is not in conflict with them or can be explained by developments in motor transport or by special circumstances.

Changes in non-commutation travel, so far as data are available, compare with those in production in the same way as changes in all travel (Tables 7,9 ). We have previously concluded that changes in commuting are milder than in other travel.

Employment probably rises and falls less among commuters than among workers in mines and factories, whose output is reflected in the Reserve index of production. Its relative regularity helps to ex-

22 Perhaps highway competition was not important enough in 1919-20 to account for the comparative movement during that reference expansion, in which travel showed a net decline while production rose. But other circumstances, of an unusual character, raised the level of passenger-miles at the business trough in April 1919 relatively to the level at the business peak in January 1920. The return movement of soldiers was large at the trough, small at the peak (Chart 8). Civilian travel at the former was probably swollen by the release of the restrictions imposed by the war and the epidemic. Something-we don't know what, but it must have been of a transient nature-caused a sharp temporary decline at the peak. 


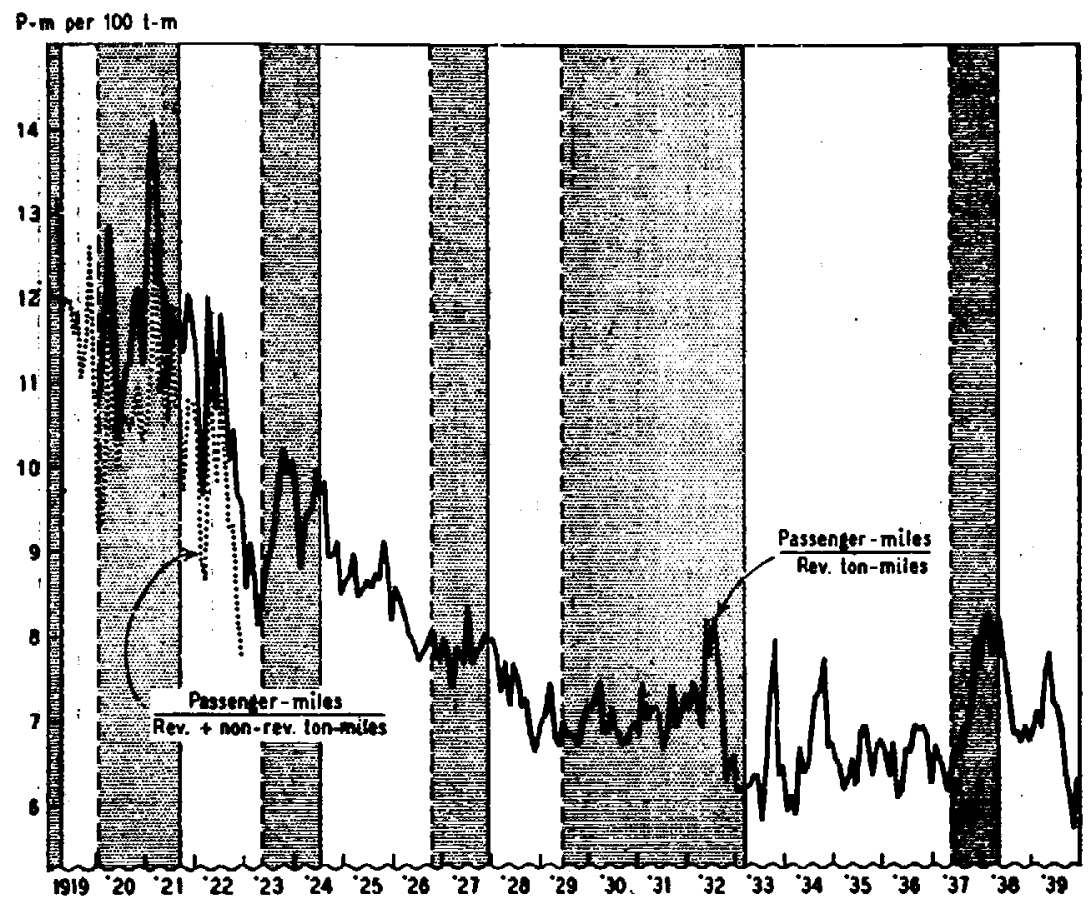

plain the relative stability of total travel of which the daily trips to and from work form a part.

\section{PASSENGER VS. FREIGHT TRAFFIC}

In four out of five expansions ton-miles rose between reference dates, while total passenger-miles rose less or declined. In the same number and percentage of contractions freight traffic declined more than travel. But in the greatest expansion (1933-37) and the greatest contraction (1929-33), travel changed more than ton-miles (Table 7). Specific phase comparisons cannot be made by the usual method for the first expansion and contraction because the beginning date of the cycle in travel is unknown. During the remaining four expansions a comparison of the change in travel between its own specific dates with the change in freight between its specific dates suggests the same conclusions as in the case of the changes between reference dates. This is true also of contractions except in 1926-27. In the specific phase corresponding to the severest contraction and the sharpest expansion, the variation in passenger-miles again appears greater 


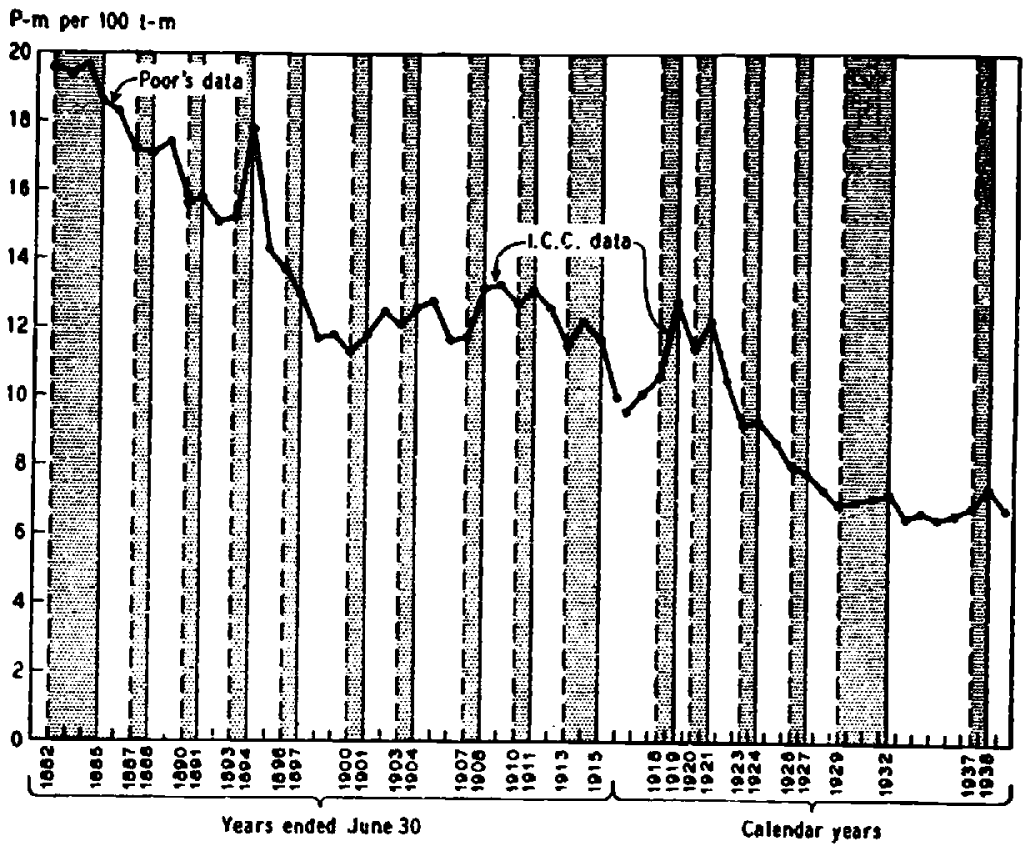

than in ton-miles. Counting this contraction, it was greater in 2 out of 4 (Table 9).

Comparison of amplitudes thus yields rather uncertain results. On the whole, it suggests that freight is affected more severely than passenger traffic by changes in business conditions. But the exceptions are too important to be ignored.

The 1929 peak in the movement of freight was higher than the 1920 peak. Most other economic activities likewise attained higher peaks in 1929. Passenger travel, on the other hand, was about onethird lower. This suggests that persistent influences were tending to depress passenger traffic relatively to freight during both expansions and contractions within the longer period. The suggestion is confirmed by an examination of the ratio of passenger-miles to ton-miles, which declined substantially over the period as a whole (Chart 13). But the fall was most conspicuous in expansions. In contractions the ratio remained fairly stationary or even rose. During the period since 1929, regarded as a whole, there has been little net change in the ratio. But during the long contraction of 1929-33 it rose somewhat except during the last four months. It rose in the contraction of 1937 - 


\section{TABLE 11}

Passenger-miles per 100 Ton-miles Rate of Change between Reference Months

\begin{tabular}{|c|c|c|c|c|c|c|c|}
\hline & & & & & CHAN & OM PRECE & IG DATE \\
\hline & & & & ASSENGER- & Total & Per & \\
\hline & & LEVEL & $\begin{array}{c}\text { MONTHS } \\
\text { FROM }\end{array}$ & $\begin{array}{c}\text { MILES } \\
\text { PER } 100\end{array}$ & & $\begin{array}{l}10 \\
\text { peak }\end{array}$ & $\begin{array}{c}\text { To } \\
\text { trough }\end{array}$ \\
\hline $\begin{array}{r}\text { REFER } \\
\text { DA }\end{array}$ & ENCE & $O F$ & PRECEDING & TON- & & from & from \\
\hline $\begin{array}{c}\text { DA? } \\
\text { April }\end{array}$ & & BUSINESS & DATE & MILES ${ }^{1}$ & & trough & peak \\
\hline April & 1919 & trough & $\ldots$ & 12.321 & & $\cdots$ & $\cdots$ \\
\hline Jan. & 1920 & peak & 9 & 9.876 & -2.445 & -0.272 & \\
\hline Sept. & 1921 & trough & 20 & 10.329 & 0.453 & & 0.023 \\
\hline May & 1923 & peak & 20 & 7.865 & -2.464 & -0.123 & $\cdots$ \\
\hline Sept. & 1921 & trough & & 11.494 & & & $\cdots$ \\
\hline May & 1923 & peak & 20 & 8.470 & -3.024 & -0.151 & $\cdots$ \\
\hline July & 1924 & trough & 14 & 9.815 & 1.345 & $\cdots$ & 0.096 \\
\hline Oct. & 1926 & peak & 27 & 7.918 & -1.897 & -0.070 & $\cdots$ \\
\hline Dec. & 1927 & trough & 14 & 7.979 & 0.061 & & 0.004 \\
\hline June & 1929 & peak & 18 & 6.842 & -1.137 & -0.063 & .. \\
\hline March & 1933 & trough & 45 & 6.213 & -0.629 & $\ldots$ & -0.014 \\
\hline May & 1937 & peak & so & 6.450 & 0.237 & 0.005 & \\
\hline May & 1938 & trough & 12 & 7.999 & 1.549 & ... & 0.129 \\
\hline
\end{tabular}

1 Ratio pertains to three months: reference, preceding, and following. Non-revenue ton-miles included in divisor, first four lines.

38 also. In the intervening expansion it was fairly flat, although it fluctuated irregularly in the earlier months.

Our usual method of computing the rate of change indicates that the ratio conformed negatively to business in every possible comparison except that of 1929-33 with 1933-37 (Table 11), in which the computation produces a fall in the contraction and a slight rise in the expansion. But the method makes use of the data for only the ends of the phases, and in the 1929-33 contraction the end of the phase is very unrepresentative of its general course. If the reference date had been placed in the summer of 1932 (when the specific turn in the Reserve index, ton-miles, and various other economic measures occurred) the arithmetic procedure would yield no exception.

We interpret the course of events depicted in Chart 13 in the following manner. Improving business conditions tended to increase freight more rapidly than passenger traffic, and hence to cause the ratio of passenger-miles to ton-miles to decline. Contraction in business tended to reduce freight more than passenger traffic, and hence to cause the ratio to rise. Expansion reenforced and contraction worked against the influence of more enduring factors. Between 1929 and 1937 more widespread and greater reductions were made in passenger fares than in freight rates. These tended to offset the other 
TABI.E 12

Passenger-Miles per 100 Ton-Miles

Rate of Change between Reference Years

\begin{tabular}{|c|c|c|c|c|c|c|}
\hline \multirow[b]{4}{*}{ REFERENCE } & \multirow{4}{*}{$\begin{array}{l}\text { LEVEL } \\
\text { OF }\end{array}$} & \multirow{4}{*}{$\begin{array}{l}\text { YEARS } \\
\text { FROM }\end{array}$} & \multirow[b]{2}{*}{ PASSENGER. } & \multirow{2}{*}{\multicolumn{3}{|c|}{$\begin{array}{l}\text { CHANGE FROM PRECEDING DATE } \\
\text { Total Per Y }\end{array}$}} \\
\hline & & & & & & \\
\hline & & & MILES & & To & To \\
\hline & & & PER 100 & & peak & trough \\
\hline DATE & BUSINESS & $\begin{array}{l}\text { PIIECEDING } \\
\text { DATE }\end{array}$ & $\begin{array}{l}\text { TON- } \\
\text { MILES }\end{array}$ & & trom & fr \\
\hline 1882 & peak & $\ldots$ & 19.56 & & trough & Pe \\
\hline 1885 & trough & 3 & 18.58 & -0.98 & $\cdots$ & \\
\hline 1887 & peak & 2 & 17.17 & -1.41 & -0.70 & -0.33 \\
\hline 1888 & trough & 1 & 17.11 & -0.06 & 0.10 & $\cdots$ \\
\hline 1890 & peak & 2 & 15.81 & -1.30 & $\ddot{n}$ & -0.06 \\
\hline & & & & -800 & -0.03 & $\cdots$ \\
\hline 1890 & peak & $\ldots$ & 15.55 & . & & \\
\hline 1891 & trough & 1 & 15.84 & 0.29 & & 0.29 \\
\hline 1893 & peak & 2 & 15.20 & -0.64 & -0.32 & $\cdots$ \\
\hline 1894 & trough & 1 & 17.79 & 2.59 & $\ldots$ & 2.59 \\
\hline 1896 & peak & 2 & 13.69 & -4.10 & -2.05 & $\ldots$ \\
\hline 1897 & trough & 1 & 12.88 & -0.81 & $\ldots$ & -0.81 \\
\hline 1900 & peak & 3 & 11.33 & -1.55 & -0.52 & .. \\
\hline 1901 & trough & 1 & 11.80 & 0.47 & $\ldots$ & 0.47 \\
\hline 1903 & peak & 2 & 12.07 & 0.27 & 0.14 & $\ldots$ \\
\hline 1904 & trough & 1 & 12.56 & 0.49 & $\ldots$ & 0.49 \\
\hline 1907 & peak & 3 & 11.72 & -0.84 & -0.28 & .. \\
\hline 1908 & trough & 1 & 13.32 & 1.60 & $\ldots$ & 1.60 \\
\hline 1910 & peak & 2 & 12.68 & -0.64 & -0.32 & $\cdots$ \\
\hline 1911 & trough & 1 & 13.08 & 0.40 & $\cdots$ & 0.40 \\
\hline 1913 & peak & 2 & 11.49 & -1.59 & -0.80 & 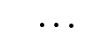 \\
\hline 1915 & trough & 2 & 11.72 & 0.23 & $\ldots$ & 0.12 \\
\hline 1918 & peak & 3.5 & 10.57 & -1.15 & --0.33 & .. \\
\hline 1919 & trough & 1 & 12.76 & 2.19 & $\ldots$ & 2.19 \\
\hline 1920 & peak & 1 & 11.45 & -1.31 & -1.31 & $\cdots$ \\
\hline
\end{tabular}

long-time influences. Perhaps the net effect was a slight tendency for passenger-miles to rise somewhat relatively to freight ton-miles. The greater stimulating effect of business expansion on freight traffic offset this tendency during the expansion; its greater depressing effect caused an actual rise in the ratio during the adjacent contractions.

Judged by annual data the course of events was similar in the decades before the monthly data begin. Over a period of several business cycles, regarded in its entirety, passenger-miles increased, but not as much as ton-miles; in general the ratio of passenger-miles to ton-miles declined (Chart 14). But it rose somewhat in many of the contractions, and declined fairly consistently in the expansions. Of the many comparisons possible, only one indicates an exception to the general rule of inverse conformity (Table 12).

In the preceding section it was suggested that the amount of travel, like the output of perishable consumer goods, changes more mildly 
than the total output of industrial commodities. Freight traffic, on the other hand, consists to a considerable extent of durable producer goods. ${ }^{23}$ The sharp variations in their supply are reflected in the quantities tendered to the railroads for transportation.

\section{CONCLUSIONS}

An increase in railway travel has usually been a feature of a general expansion in business. In some of the expansions that have occurred since the development of highways and motoring, however, the increase in rail travel was brief and small, and there was a net decline in passenger-miles between the beginning and the end of the general upward movement. In a business contraction rail travel usually either declined or grew less rapidly than in expansion.

The average length of journeys, at least in recent cycles, likewise conforms positively to the general changes in business. The length of commutation trips, however, has increased somewhat more rapidly in contraction than in expansion.

The time at which an expansion in travel began or ended has usually been influenced, during the period for which records are available, by the continuously increasing attractiveness of highway travel or by circumstances such as do not recur in most cycles-the Armistice and an epidemic in 1918, the banking holiday in 1933. But there is a little evidence that in the absence of such complications peaks in traffic would come somewhat late in the transition from prosperity to depression, and troughs somewhat late in the opposite process.

Commuting is less affected by business conditions than other travel. Cyclical changes in total passenger traffic are likely to be milder than in industrial production or in freight traffic.

${ }^{23}$ See our Occasional Paper S, Freight Traffic in Prosperity and Depression, p. 32. 


\section{Occasional Papers}

1 Manufacturing Output, 1929-1937 (December 1940) Solomon Fabricant

2 National Income, 1919-1938 (April 1941) Simon Kuznets

3 Finished Com modities Since 1879, OutPut and Its Compostrion (August 1941) William H. Shat

4 The Relation Bftween Factory Employment and OutPut SINCE 1899 (December 1941) Solomon Fabricant

5 Railofay Freight Traffic in Prosperity and Depression (February 1942) Thor Huligren

6 Uses of National Incomf in Peace and War (March 1942) Simon Kuznets

7 Productivity of Labor in Peace and War (September 1942) Solomon Fabricant

8 The Banking System and War Finance (February 1943) Charles $R$. Whittlesey

9 Wartime 'Prosperity' and the Future (March 1943) Wesley C. Mitchell

10 The Effect of War on Business Financing: Manufacturing aNd Trade, World War I (November 1943)

Ralph A. Young and Charles H. Schmidt

11 The Effect of War on CuRRencr and Deposits (September 1943) Charles $R$. Whitllesey

12 Prices in a War economy: Some Aspects of the Present Price, Structure of ThF. UNITEd States (October 1943)

Frederick C. Mills

13 Railroad Travel. and the State of Busintss (December 1943) Tbor Hultgren

14 The Labor Force in Wartime America (December 1943) Clarence D. Long

15 Railway Traffic Expanston and Use of Resources in WORLD WAR II (in press) Thor Hultgren

\section{Technical Papers}

1 A Significance Test for Time Series and Other Ordered ObServations (September 1941) $W$. Allen $W$ allis and Geoffrey $H$. Moove

2 The Relation of Cost to Output for a leather Belt Shop (December 1941) Joel Dean, with a Memorandum on Certain Problems in the Empirical Study of Costs by $C$. Reinold Noyes

3 Basic Yields of Corporate Bondd, $1900-1942$ (June 1942) David Durand 